\title{
Black carbon in the atmosphere and snow, from pre-industrial times until present
}

\author{
R. B. Skeie ${ }^{1}$, T. Berntsen ${ }^{1,2}$, G. Myhre ${ }^{1}$, C. A. Pedersen ${ }^{3}$, J. Ström ${ }^{3}$, S. Gerland ${ }^{3}$, and J. A. Ogren ${ }^{4}$ \\ ${ }^{1}$ Center for International Climate and Environmental Research - Oslo (CICERO), Oslo, Norway \\ ${ }^{2}$ Department of Geosciences, University of Oslo, Oslo, Norway \\ ${ }^{3}$ The Norwegian Polar Institute, Fram Centre, Troms $\varnothing$, Norway \\ ${ }^{4}$ Earth System Research Laboratory, National Oceanic and Atmospheric Administration, Boulder, Colorado, USA
}

Received: 1 February 2011 - Published in Atmos. Chem. Phys. Discuss.: 4 March 2011

Revised: 8 July 2011 - Accepted: 11 July 2011 - Published: 18 July 2011

\begin{abstract}
The distribution of black carbon (BC) in the atmosphere and the deposition of $\mathrm{BC}$ on snow surfaces since pre-industrial time until present are modelled with the Oslo CTM2 model. The model results are compared with observations including recent measurements of $\mathrm{BC}$ in snow in the Arctic. The global mean burden of BC from fossil fuel and biofuel sources increased during two periods. The first period, until 1920, is related to increases in emissions in North America and Europe, and the last period after 1970 are related mainly to increasing emissions in East Asia. Although the global burden of BC from fossil fuel and biofuel increases, in the Arctic the maximum atmospheric BC burden as well as in the snow was reached in 1960s, with a slight reduction thereafter. The global mean burden of $\mathrm{BC}$ from open biomass burning sources has not changed significantly since 1900. With current inventories of emissions from open biomass sources, the modelled burden of $\mathrm{BC}$ in snow and in the atmosphere north of $65^{\circ} \mathrm{N}$ is small compared to the $\mathrm{BC}$ burden of fossil fuel and biofuel origin. From the concentration changes radiative forcing time series due to the direct aerosol effect as well as the snow-albedo effect is calculated for $\mathrm{BC}$ from fossil fuel and biofuel. The calculated radiative forcing in 2000 for the direct aerosol effect is $0.35 \mathrm{~W} \mathrm{~m}^{-2}$ and for the snow-albedo effect $0.016 \mathrm{~W} \mathrm{~m}^{-2}$ in this study. Due to a southward shift in the emissions there is an increase in the lifetime of $\mathrm{BC}$ as well as an increase in normalized radiative forcing, giving a change in forcing per unit of emissions of $26 \%$ since 1950 .
\end{abstract}

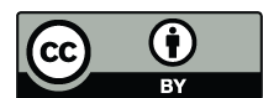

Correspondence to: R. B. Skeie (r.b.skeie@ cicero.uio.no)

\section{Introduction}

Black carbon aerosols (BC) are emitted to the atmosphere from incomplete combustion of biomass and fossil fuel. The source of $\mathrm{BC}$ can be of natural (lightning-induced forest fires) or anthropogenic origin (e.g. coal burning, diesel combustion and wood burning). Black carbon can alter the climate in several ways. Black carbon aerosols absorb solar radiation and hence warm the atmosphere (Haywood and Shine, 1995) ("the direct aerosol effect"). Black carbon deposited in and on snow and ice surfaces darkens the surface and reduces the surface albedo (Warren and Wiscombe, 1980; Hansen and Nazarenko, 2004) ("BC-albedo effect"). This can directly trigger the snow albedo feedback through acceleration of snow melt, giving a further warming (Flanner et al., 2009). Black carbon may also affect clouds. Atmospheric heating through the direct aerosol effect perturbs the stability of the atmosphere and therefore cloud distributions, potentially causing warming or cooling, commonly termed the "semi-direct effect" (Koch and Del Genio, 2010). Black carbon aerosols might also affect warm clouds by acting as cloud condensation nuclei (CCN) giving brighter clouds and reducing precipitation (Kristjansson, 2002; Bauer et al., 2010; Chen et al., 2010; Jacobson, 2010) ("the indirect effect"). Finally, BC particles may also act as ice nuclei affecting cold or mixed-phase clouds. All the effects through cloud modifications are poorly understood, and estimates are uncertain in magnitude and even sign (Liu et al., 2009; Penner et al., 2009).

In our study we focus on the direct aerosol effect and the $\mathrm{BC}$-albedo effect and how the concentration and deposition of $\mathrm{BC}$ have changed from pre-industrial times until present. Unlike other climate forcing agents, $\mathrm{BC}$ is emitted due to

Published by Copernicus Publications on behalf of the European Geosciences Union. 
incomplete combustions and the climate effect is therefore not directly proportional to fuel use. Therefore there will be significant changes over time and regional differences that will influence the radiative forcing time series of $\mathrm{BC}$ and calculations of radiative forcing trends of $\mathrm{BC}$ are needed. The total emission of $\mathrm{BC}$ from fossil fuel and biofuel combustion has increased almost linearly from 1850 to 2000 (Bond et al., 2007), but the relative regional contributions have changed significantly. In the early period (until around 1950), North America and Europe were the main source regions, but improved combustion technology and fuel switch in these regions have reduced the emissions during the last part of the 20th century. China and the rest of Asia have had a large increase in emissions over the three last decades. Black carbon has a relatively short lifetime in the atmosphere, approximately one week (Schulz et al., 2006), so the climate effect of $\mathrm{BC}$ emissions is dependent on where the emissions take place. The changes in the geographical distribution of the emissions will also affect the lifetime of $\mathrm{BC}$ aerosols and hence the climate effect.

Globally the radiative forcing (RF) of climate between 1750 and 2005 for BC with fossil fuel origin is estimated to be $0.2[ \pm 0.15] \mathrm{W} \mathrm{m}^{-2}$ for the direct aerosol effect (Forster et al., 2007). Ramanathan and Carmichael (2008) calculated the radiative forcing of the $\mathrm{BC}$ direct aerosol effect to be $0.9 \mathrm{~W} \mathrm{~m}^{-2}$ (range $0.4-1.2 \mathrm{~W} \mathrm{~m}^{-2}$ ) based on an observationally-constrained study of Chung et al. (2005). This RF estimate also includes BC from open biomass burning. Black carbon from open biomass burning is essentially uncontrolled and co-emitted with significant amounts of organic aerosols giving a net estimated RF of 0.03 $[ \pm 0.12] \mathrm{W} \mathrm{m}^{-2}$ (Forster et al., 2007). Therefore the RF direct aerosol effect from open biomass burning $\mathrm{BC}$ is not included in this study. For the snow albedo effect the IPCC reported a radiative forcing of $0.10[ \pm 0.10] \mathrm{W} \mathrm{m}^{-2}$. More recently Flanner et al. (2007), Rypdal et al. (2009) and Koch et al. (2009a) have estimated a substantially lower radiative forcing of $\mathrm{BC}$ in snow of $0.05,0.03$ and $0.01 \mathrm{~W} \mathrm{~m}^{-2}$, respectively. However, Flanner et al. (2007) found a high efficacy factor (2.1-4.5) for the snow albedo forcing.

It has been argued that cutting the emissions of $\mathrm{BC}$ may be important to slow the observed rapid warming in the Arctic region (Quinn et al., 2008). Long-term observations of BC at surface stations in the Arctic (Sharma et al., 2004; Eleftheriadis et al., 2009) as well as aircraft campaign data (ARCPAC: Warneke et al., 2009; ARCTAS: Jacob et al., 2010; Brock et al., 2011) show that BC concentrations build up during spring as part of the Arctic haze phenomena (Shaw and Stamnes, 1980; Iversen and Joranger, 1985; Shaw, 1995). However, many models have problems in capturing the enhanced winter-spring concentrations in the Arctic (Shindell et al., 2008; Koch et al., 2009b). Most of these models do not include aerosol microphysics that lead to conversion of $\mathrm{BC}$ to a hydrophilic state where it can be scavenged by precipitation (commonly referred to as aging), and only include the aging through a single time constant (Cooke et al., 1999). In this work we introduce aging times depending on latitude and season in a simple bulk scheme for $\mathrm{BC}$, which improves the simulation of the Arctic Haze phenomena, as also found in Liu et al. (2011). The aging times used in this study are based on simulations using the M7 module (Vignati et al., 2004). Other models including aerosol microphysics are e.g. Bauer et al. (2010) and Jacobson (2001).

For validation of the model results in the atmosphere and in the snow, a few long time series of BC measurements in the Arctic exist (McConnell et al., 2007; McConnell and Edwards, 2008). Data from two ice cores from Greenland show high concentrations around 1900-1920 and then a steep decline. However, as Greenland is directly downwind from North American sources, model simulations (Law and Stohl, 2007; Hirdman et al., 2010) show that BC in air close to the surface in other parts of the Arctic is mainly influenced by sources in Eurasia. Thus BC from the Greenland ice cores can not be expected to be representative for the historical development of $\mathrm{BC}$ in snow in the Arctic region.

In this study we use a global chemical transport model (CTM) to investigate the changes in burden of BC in the atmosphere and deposition on snow surfaces from preindustrial time and until present. The model results are compared to surface measurements, observations from aircraft and measurements of $\mathrm{BC}$ in snow and ice cores. A special emphasis is given to the Arctic region. Radiative forcing time series for the direct aerosol effect of $\mathrm{BC}$ from fossil fuel and biofuel sources and RF-time series for BC snow albedo effect from fossil fuel and biofuel combustion are presented. This is important for knowing how much BC has contributed to global warming and for constraining the climate sensitivity (e.g. Knutti and Hegerl, 2008) by combining radiative forcing time series and observed temperature changes.

\section{Model and setup}

The atmospheric chemistry transport model Oslo CTM2 (Berglen et al., 2004; Berntsen et al., 2006; Søvde et al., 2008; Myhre et al., 2009; Rypdal et al., 2009) is used to calculate $\mathrm{BC}$ concentration in the atmosphere and the deposition of $\mathrm{BC}$ on snow surfaces using emission inventories for fossil fuel, biofuel and open biomass burning. Time slice simulations for the years 1750, 1850 and every 10th year from 1900 until year 2000 have been done. In these simulations the meteorological input is equal for all years, starting in August 2005 until the end of 2006. The changes in BC concentrations do not feed back on the meteorological data. In addition simulations for the years 2001 to 2008 using meteorological data for the years simulated are performed for the verification of the model. The changes in concentration of $\mathrm{BC}$ in the atmosphere and in the snowpack are used in a radiative transfer code (Stamnes et al., 1988; Myhre et al., 2009) for calculating RF history of both direct aerosol effect and the 
BC-albedo effect. Simulations with regional emissions from the main emissions regions are done for the years 1930 and 2000.

\subsection{The Oslo CTM2 model}

Oslo CTM2 is a large scale off-line chemical transport model driven by meteorological data generated by the Integrated Forecast System (IFS) model at the European Centre for Medium-Range Weather Forecasts (ECMWF). The resolutions used here are T42 $(2.8 \times 2.8$ degrees $)$ in the horizontal and 60 vertical levels from the surface to $0.1 \mathrm{hPa}$.

Advection of tracers are calculated using a second order moment scheme (Prather, 1986) that is low-diffusive, has high accuracy and is able to maintain large gradients in the distribution of species. Vertical mixing by convection is based on mass flux data from IFS (Tiedtke, 1989), and an "elevator" principle, surplus or deficit of mass in a column (described in Berglen et al., 2004). Turbulent mixing in the boundary layer is treated according to the Holtslag K-profile scheme (Holtslag et al., 1990).

The carbonaceous aerosol scheme is based on the simple bulk scheme of Cooke et al. (1999). The conversion from hydrophobic (uncoated, or non water-soluble coatings) to hydrophilic (coated with water-soluble species) aerosols in models is often treated with a constant exponential lifetime (Cooke et al., 1999). This is a simplification since the aging depends on coagulation with soluble aerosols and condensation of organics and inorganic species. In this work we introduce aging times depending on latitude and season. This improved the modelled seasonal cycle at Arctic monitoring stations, with enhanced concentrations during winter (Sharma et al., 2006; Eleftheriadis et al., 2009). The aging time dependencies on latitude and season are estimated based on simulations with the full tropospheric chemistry version of Oslo CTM2 with the M7 aerosol microphysical module (Vignati et al., 2004). This model version allows for condensation of sulphuric acid and coagulation of sulphate on BC particles which determines the aging time, but excludes other effects. The M7 version may therefore overestimate the aging time. Due to computing time limitations we were not able to do all simulations with the coupled model system. Simulations using the M7 version of Oslo CTM2 with regional emissions are done and lifetimes are calculated (Lund and Berntsen, 2011 in preparation), and latitudinal and seasonal aging is estimated (Table 1) based on these simulations and corresponding emissions. Oxidation of $\mathrm{SO}_{2}$ to sulphate is slower during winter at high latitudes, which leads to significantly slower aging. The aging times at high latitudes vary from 1.2 in summer to 5 days in winter, while at low latitudes and in the Southern Hemisphere there is much less variation and a value of 1.5 days is used for all seasons. A description of the removal processes in the carbonaceous scheme is given in Appendix A.
Table 1. Aging times (days) dependent on latitude and season.

\begin{tabular}{lcccc}
\hline${ }^{\circ} \mathrm{N}$ & Winter & Spring & Summer & Autumn \\
\hline$<28$ & 1.5 & 1.5 & 1.5 & 1.5 \\
$28-31$ & 1.5 & 1.5 & 1.5 & 1.5 \\
$31-33$ & 1.3 & 1.4 & 1.5 & 1.4 \\
$33-36$ & 1.1 & 1.1 & 1.6 & 1.3 \\
$36-39$ & 1.1 & 1.1 & 1.5 & 1.3 \\
$39-42$ & 1.2 & 1.1 & 1.5 & 1.4 \\
$42-45$ & 1.4 & 1.2 & 1.5 & 1.5 \\
$45-47$ & 1.9 & 1.4 & 1.5 & 1.8 \\
$47-50$ & 2.0 & 1.4 & 1.4 & 1.8 \\
$50-53$ & 3.4 & 1.5 & 1.4 & 2.1 \\
$53-56$ & 4.6 & 1.6 & 1.3 & 2.3 \\
$56-59$ & 5.4 & 2.0 & 1.7 & 2.8 \\
$59-61$ & 5.8 & 2.3 & 1.9 & 3.1 \\
$61-64$ & 5.2 & 1.9 & 1.6 & 2.6 \\
$64-67$ & 4.8 & 1.7 & 1.5 & 2.5 \\
$67-70$ & 5.0 & 1.8 & 1.5 & 2.6 \\
$70-73$ & 5.6 & 2.1 & 1.8 & 2.9 \\
$73-75$ & 5.5 & 2.1 & 1.7 & 2.8 \\
$75-78$ & 5.2 & 1.9 & 1.6 & 2.6 \\
$78-81$ & 4.6 & 1.5 & 1.2 & 2.2 \\
$81-84$ & 4.6 & 1.5 & 1.2 & 2.2 \\
$84-87$ & 4.6 & 1.5 & 1.2 & 2.2 \\
$87-90$ & 4.6 & 1.5 & 1.2 & 2.2 \\
\hline
\end{tabular}

The Oslo CTM2 includes a routine for calculating the BC concentration in snow (Rypdal et al., 2009). Data on snow fall, melt and evaporation from the meteorological data driving the model are used to generate and remove snow layers in each grid box (maximum 10 layers). In these snow layers the amounts of deposited $\mathrm{BC}$ are stored, and the concentration of $\mathrm{BC}$ in each snow layer is calculated. A description of the routine is given in Appendix B.

\subsection{Radiative forcing}

The radiative transfer calculations are performed with a multi-stream model using the discrete ordinate method (Stamnes et al., 1988). Solar absorption by gases and scattering by clouds and Rayleigh scattering are included as well as scattering and absorption by different aerosol types (Myhre, 2009; Myhre et al., 2009). The global calculations are performed using the same ECMWF meteorological data (cloud distribution and humidity) and resolution as in the CTM simulations. In the calculations of radiative forcing for $\mathrm{BC}$ from fossil fuel and biofuel, the present levels of the other aerosol types such as mineral dust, sea salt, sulphate, nitrate, primary organic carbon (OC) from fossil fuel, secondary organic aerosols, and biomass burning aerosols (BC and $\mathrm{OC}$ ) are included.

The optical properties of BC are calculated based on Mie theory and involves information of aerosol size and refractive 
Table 2. Global mean annual emissions, burdens, and lifetimes for BC fossil fuel and biofuel (FFBF) and BC biomass burning (BB) in addition to emission north of $40^{\circ} \mathrm{N}(\mathrm{N} 40)$ and burden in atmosphere north of $65^{\circ} \mathrm{N}(\mathrm{N} 65)$ and burden in snow north of $65^{\circ} \mathrm{N}$ end of April.

\begin{tabular}{|c|c|c|c|c|c|c|c|c|c|c|c|c|}
\hline & \multicolumn{2}{|c|}{$\begin{array}{l}\text { Emission } \\
\left(\mathrm{Tg} \mathrm{yr}^{-1}\right)\end{array}$} & \multicolumn{2}{|c|}{$\begin{array}{l}\text { Global mean } \\
\text { burden }(\mathrm{Gg})\end{array}$} & \multicolumn{2}{|c|}{$\begin{array}{l}\text { Lifetime } \\
\text { (days) }\end{array}$} & \multicolumn{2}{|c|}{$\begin{array}{c}\text { Emission } \\
\mathrm{N} 40\left(\mathrm{Tg} \mathrm{yr}^{-1}\right)\end{array}$} & \multicolumn{2}{|c|}{$\begin{array}{c}\text { Burden } \\
\text { N65 (Gg) }\end{array}$} & \multicolumn{2}{|c|}{$\begin{array}{c}\text { Burden N65 in } \\
\text { snow end of } \\
\text { April (Gg) }\end{array}$} \\
\hline & FFBF & $\mathrm{BB}$ & FFBF & BB & FFBF & $\mathrm{BB}$ & FFBF & BB & FFBF & $\mathrm{BB}$ & FFBF & BB \\
\hline 1750 & 0.4 & 1.0 & 7 & 25 & 6.3 & 9.0 & 0.2 & 0.1 & 0.4 & 0.4 & 1.7 & 0.4 \\
\hline 1850 & 1.0 & 2.0 & 18 & 50 & 6.3 & 9.0 & 0.7 & 0.3 & 1.1 & 0.7 & 4.5 & 0.8 \\
\hline 1900 & 2.3 & 2.0 & 39 & 50 & 6.2 & 9.0 & 1.6 & 0.3 & 2.4 & 0.7 & 11 & 0.8 \\
\hline 1910 & 2.8 & 2.0 & 49 & 48 & 6.2 & 9.0 & 2.0 & 0.3 & 3.0 & 0.7 & 13 & 0.8 \\
\hline 1920 & 3.0 & 1.8 & 52 & 44 & 6.2 & 9.1 & 2.1 & 0.1 & 3.0 & 0.4 & 13 & 0.5 \\
\hline 1930 & 2.9 & 1.8 & 51 & 45 & 6.3 & 9.2 & 2.0 & 0.1 & 3.1 & 0.4 & 14 & 0.4 \\
\hline 1940 & 3.0 & 1.7 & 52 & 44 & 6.4 & 9.2 & 2.0 & 0.1 & 3.2 & 0.3 & 15 & 0.4 \\
\hline 1950 & 3.1 & 1.7 & 54 & 44 & 6.4 & 9.3 & 2.1 & 0.1 & 3.2 & 0.3 & 15 & 0.3 \\
\hline 1960 & 3.4 & 1.8 & 60 & 46 & 6.5 & 9.2 & 2.0 & 0.1 & 3.4 & 0.3 & 16 & 0.2 \\
\hline 1970 & 3.3 & 2.1 & 61 & 53 & 6.7 & 9.2 & 1.7 & 0.1 & 2.8 & 0.3 & 13 & 0.2 \\
\hline 1980 & 3.9 & 2.3 & 73 & 58 & 6.9 & 9.2 & 1.5 & 0.1 & 2.6 & 0.4 & 11 & 0.2 \\
\hline 1990 & 4.4 & 2.7 & 84 & 69 & 6.9 & 9.2 & 1.5 & 0.1 & 2.7 & 0.5 & 12 & 0.3 \\
\hline 2000 & 4.5 & 2.6 & 89 & 65 & 7.2 & 9.0 & 1.2 & 0.3 & 2.3 & 0.8 & 8.5 & 0.7 \\
\hline 2001 & 4.9 & 2.5 & 97 & 59 & 7.2 & 8.7 & 1.1 & 0.2 & 2.3 & 0.6 & 5.3 & 0.6 \\
\hline 2002 & 4.9 & 2.7 & 99 & 64 & 7.3 & 8.5 & 1.1 & 0.4 & 2.3 & 1.3 & 7.9 & 0.5 \\
\hline 2003 & 5.0 & 2.6 & 100 & 60 & 7.3 & 8.5 & 1.1 & 0.5 & 2.4 & 1.1 & 9.9 & 0.9 \\
\hline 2004 & 5.0 & 2.7 & 101 & 65 & 7.4 & 8.9 & 1.1 & 0.2 & 2.4 & 0.8 & 9.0 & 1.0 \\
\hline 2005 & 5.1 & 2.7 & 103 & 67 & 7.4 & 8.9 & 1.1 & 0.2 & 2.4 & 0.7 & 9.0 & 0.7 \\
\hline 2006 & 5.1 & 2.5 & 105 & 58 & 7.5 & 8.5 & 1.1 & 0.2 & 2.4 & 0.7 & 8.2 & 0.8 \\
\hline 2007 & 5.1 & 2.7 & 113 & 68 & 8.0 & 9.1 & 1.1 & 0.2 & 2.9 & 0.5 & 9.5 & 0.8 \\
\hline 2008 & 5.2 & 2.1 & 113 & 52 & 8.0 & 9.1 & 1.1 & 0.3 & 3.3 & 0.8 & 11 & 1.3 \\
\hline
\end{tabular}

indexes (Myhre et al., 2007). The absorption efficiency for BC $\left(7.3 \mathrm{~m}^{2} \mathrm{~g}^{-1}\right)$ is close to the recommended value of $7.5 \mathrm{~m}^{2} \mathrm{~g}^{-1}$ from Bond and Bergstrom (2006). In the atmosphere it is observed that $\mathrm{BC}$ is a combination of external and internal mixtures (Horvath, 1993; Hara et al., 2003; Wentzel et al., 2003; Mallet et al., 2004; Cheng et al., 2006). Further, it is well known that an internal mixture for $\mathrm{BC}$ enhances the absorption compared to an external mixture. We follow the suggestion by Bond et al. (2006) of increasing the absorption due to hydrophilic $\mathrm{BC}$ by $50 \%$ to take into account coating and thus internal mixing for these $\mathrm{BC}$ particles, but no enhancement in the absorption of hydrophobic $\mathrm{BC}$ since these are treated as external mixtures. This is a core-shell internal mixing of $\mathrm{BC}$. We note that this is a simplification of the aging process of $\mathrm{BC}$ and the coating of $\mathrm{BC}$ with no enhanced absorption for the intermediate stages between hydrophilic and hydrophobic BC. However, given the uncertainties in the absorption efficiency of $\mathrm{BC}$ the approach suggested by Bond et al. (2006) is useful.

The global radiative forcing calculations of $\mathrm{BC}$ impact on snow are performed with pre-calculated look up tables (LUT) of the BC impact on snow albedo and the same radiative transfer model as adopted for the direct aerosol effect and described above. The LUT of snow albedo was calculated with a multi-stream model using the discrete ordinate method (Stamnes, 1988) with 33 atmospheric layers and extended with 2 snow layers. The snow layers in the CTM model was reduced to two layers, with $1 \mathrm{~mm}$ water equivalent thickness in the uppermost layer. The optical properties of snow and hydrophilic BC were calculated with Mie theory. The surface albedo was simulated as a function of vegetation type and the snow albedo from the LUT and an effective snow grain size of $500 \mu \mathrm{m}$ is adopted (see further description in Rypdal et al., 2009).

\subsection{Emissions}

For the historical period, emission data of $\mathrm{BC}$ from fossil fuel and biofuel (FFBF) from Bond et al. (2007) are used. Biofuel was the largest contributor to BC emissions until 1890, and then coal combustion became the main source. After 1990, diesel was the main source to FFBF BC emissions. The total BC emitted globally has increased continuously (Table 2 and Fig. 1a), but the regional emissions have a different development. North American emissions were 3 times as large around 1920 compared to year 2000. European emissions were twice as high in the period 1900-1960 compared to year 2000. The former Soviet Union has had a decrease in 

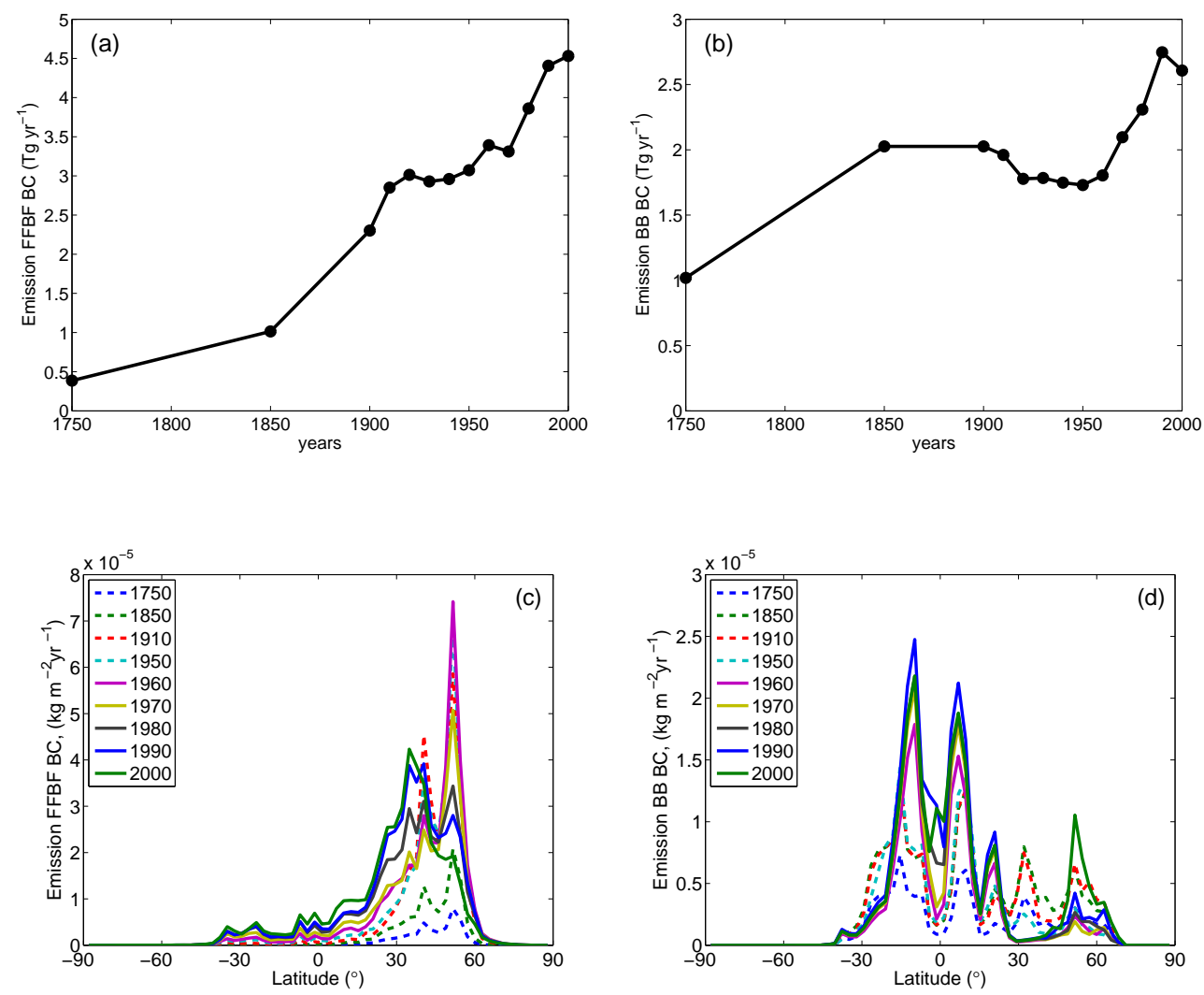

Fig. 1. Historical development of total emissions from fossil fuel and biofuel (a) and biomass burning (b). Zonal annual mean BC emissions from fossil fuel and biofuel (c) and biomass burning (d) for selected years for the historical simulations.

the emissions in the late 20th century due to economic recession, while China and other Asian countries have had rapid growth in the emissions after 1970.

Since year 2000, China and the Asian region have continued their rapid economic growth. For the Asian region the emission inventory (REAS) covers the years 1980-2003 with projections until 2010 (Ohara et al., 2007). For the simulations of the years 2001-2008, the year 2000 data from Bond et al. (2007) is used with the REAS emissions in the Asian region. The Asian emissions increased by $10 \%$ between 2000 and 2008, and the REAS inventory had $16 \%$ higher emission in year 2000 than the inventory from Bond et al. (2007).

The annual zonal mean emissions of FFBF BC for each year are shown in Fig. 1c. Most of the emissions take place in the Northern Hemisphere between 30 and $60^{\circ} \mathrm{N}$. The emissions between 50 and $60^{\circ} \mathrm{N}$ have been reduced by about $70 \%$ in year 2000 compared to 1960, while emissions south of $40^{\circ} \mathrm{N}$ have increased by $50-100 \%$ in the same period.

The emission inventory used for the historical emissions of $\mathrm{BC}$ from biomass burning (BB) are from Lamarque et al. (2010). For the 2001-2008 simulations the emissions are taken from the GFED emission database (van der Werf et al., 2006). The global emissions are shown in Fig. 1b and summarized in Table 2. In 1900 the emissions were $2.0 \mathrm{Tg} \mathrm{yr}^{-1}$, thereafter the emissions decreased to $1.7 \mathrm{Tg} \mathrm{yr}^{-1}$ by 1950 , followed by an increase until 1990 to $2.6 \mathrm{Tg} \mathrm{yr}^{-1}$. The zonal mean emissions of BB BC are shown in Fig. 1d. Worth noting is that the emissions around $30^{\circ} \mathrm{N}$ are substantially reduced since the early 20th century, and that emissions between 50 and $60^{\circ} \mathrm{N}$ increased remarkably between 1990 and 2000.

For the simulation with pre-industrial emission (year 1750), fossil fuel emissions of BC are zero, while the total biofuel and biomass burning emissions are taken from Dentener et al. (2006), as used in the AeroCom project (Schulz et al., 2006). To get consistent emission data for 1750 and the rest of the historical period, the 1850 gridded emission data are scaled down with the total numbers from the 1750 emission data. This will put somewhat too large BC emissions in the early industrialized regions, however the total anthropogenic BC emissions in 1750 were quite low $\left(0.4 \mathrm{Tg} \mathrm{yr}^{-1}\right)$ so that the errors are small.

\section{Results}

In this section the model results are presented and compared with available observations. First the results for the current period, 2000-2008 are presented, followed by results for the 

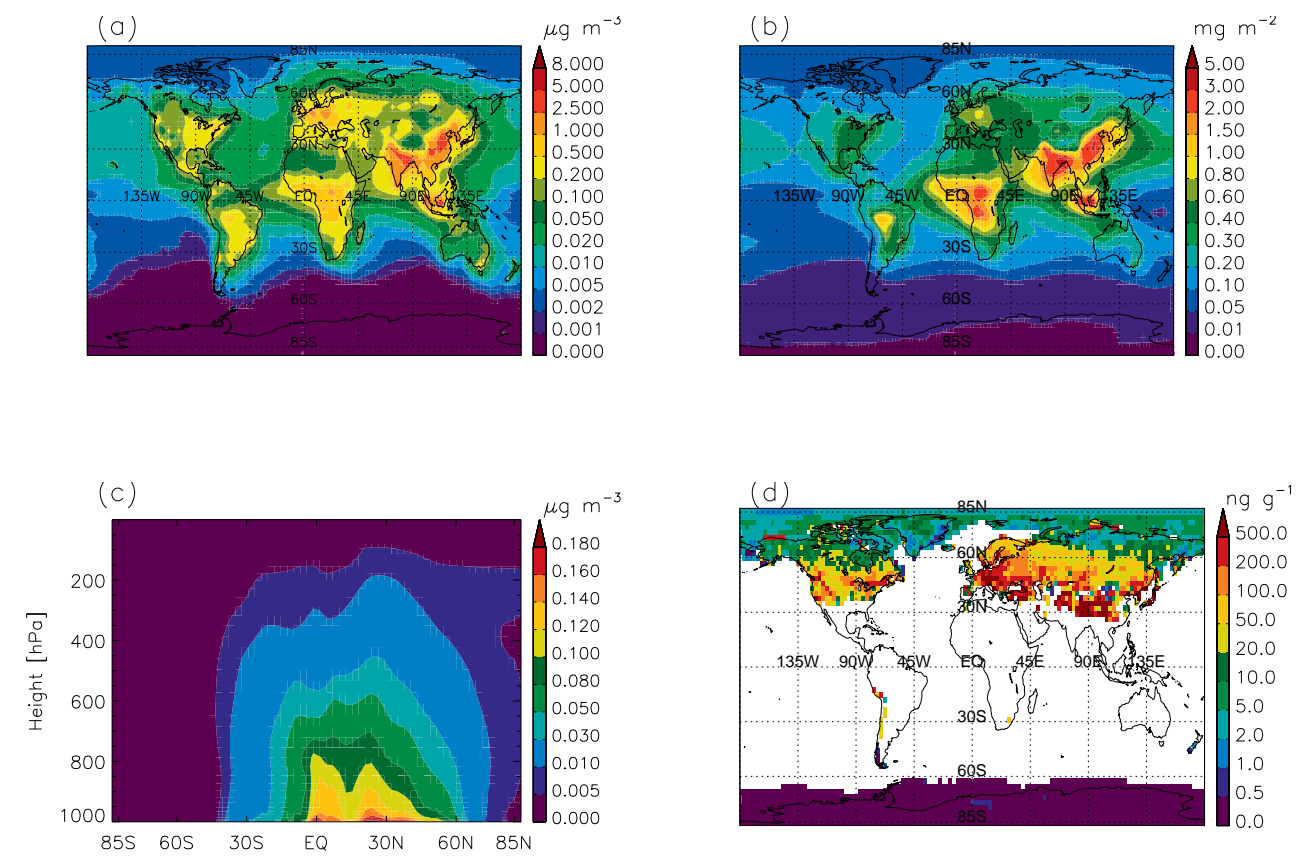

Fig. 2. Modelled annual mean $\mathrm{BC}$ concentration at the surface (a), burden of $\mathrm{BC}$ in the atmosphere (b), zonal averaged annual concentrations of BC (c) and averaged concentration of BC in surface snow (uppermost $5 \mathrm{~cm}$ ) for March, April and May (d). All figures are for the year 2006 simulation.

historical period. Both periods are separated into an atmospheric section and a snow section. At the end, regional contributions to the historical distribution of $\mathrm{BC}$ and the calculated radiative forcing time series are presented.

\subsection{Black carbon in the atmosphere, 2000-2008}

Figure 2a shows the modelled annual mean concentration of $\mathrm{BC}$ in the atmospheric surface layer (approximately $16 \mathrm{~m}$ ) for the year 2006 including both fossil fuel, biofuel and open biomass burning aerosols. The global and annual mean concentration at the surface is $0.13 \mu \mathrm{g} \mathrm{m}^{-3}, 0.25 \mu \mathrm{g} \mathrm{m}^{-3}$ over land and $0.04 \mu \mathrm{g} \mathrm{m}^{-3}$ over ocean. The highest concentrations are found over industrialized areas in East Asia, Europe and North America as well as biomass burning areas in the tropics. In the polar region, the concentrations in the European and Russian sector are higher than in the American sector.

Different observational methods are used to derive the concentration of $\mathrm{BC}$ in the atmosphere. Optical methods give equivalent black carbon (EBC) and thermal and thermooptical methods provide elemental carbon (EC). In the following we use the term $\mathrm{BC}$ when comparing observations of $\mathrm{EC}$ or $\mathrm{EBC}$ to the model results of $\mathrm{BC}$, although the resulting concentrations from different measurement methods can differ substantially (Hitzenberger et al., 2006; Vignati et al., 2010). This is discussed further in Sect. 4. Koch et al. (2009b) summarized observations of BC from the IMPROVE network (1995-2001), EMEP network (2002-2003) and observations from China from Zhang et al. (2008). Annual averages of observed BC concentrations at the surface in China were $1-14 \mu \mathrm{g} \mathrm{m}^{-3}$, in Europe $0.5-5 \mu \mathrm{g} \mathrm{m}^{-3}$, in the United States $0.1-0.5 \mu \mathrm{g} \mathrm{m}^{-3}$ and $0.01-0.1 \mu \mathrm{g} \mathrm{m}^{-3}$ for high northern latitudes. The modelled annual surface pattern (Fig. 2a) is in general good agreement with the observations listed above, however the modelled surface concentrations seems to be too low compared with the observations. A more detailed comparison with observations is given below.

Figure $2 \mathrm{~b}$ shows the annual column burden of $\mathrm{BC}$ for 2006. The global and annual mean burden is $0.31 \mathrm{mg} \mathrm{m}^{-2}$ $(160 \mathrm{Gg})$. This is in agreement with the results from the AeroCom model study which summarized annual mean burden of $\mathrm{BC}$ from published studies to be $0.37 \mathrm{mg} \mathrm{m}^{-2}$ and from models using AeroCom emissions to be $0.25 \mathrm{mg} \mathrm{m}^{-2}$ both with a standard deviation of $0.08 \mathrm{mg} \mathrm{m}^{-2}$ (Schulz et al., 2006). The calculated global mean burden for the period 2001-2008 ranged between 160-180 Gg of which biomass burning aerosols accounted for 32 to $40 \%$ (Table 2). The lifetime of the $\mathrm{BC}(\mathrm{BB}+\mathrm{FFBF})$ aerosols ranged from 7.7 to 8.4 days in the same period. The AeroCom models reported a mean lifetime of 7.12 days with a standard deviation of $33 \%$.

For the zonal annual mean concentrations of $\mathrm{BC}$ for the year 2006 (Fig. 2c), there are two maxima, one at the equator related to biomass burning and one at $20^{\circ} \mathrm{N}$ related to fossil fuel emissions in Asia. In the Arctic, the concentration increases with altitude. Transport of BC from lower latitudes towards the Arctic along isentropic trajectories might not 
Table 3. Description of measurements shown in Fig. 3.

\begin{tabular}{|c|c|c|c|c|c|c|c|c|}
\hline Name & & Location & & Site type & Contributor & Observed & Observation method & $\begin{array}{l}\text { Observation } \\
\text { years }\end{array}$ \\
\hline Zeppelin & $11.9^{\circ} \mathrm{E}$ & $78.9^{\circ} \mathrm{N}$ & $474 \mathrm{~m}$ & Arctic & Johan Ström & $\mathrm{EBC}$ & PSAP* & 2002-2008 \\
\hline Barrow & $156.6^{\circ} \mathrm{W}$ & $71.3^{\circ} \mathrm{N}$ & $11 \mathrm{~m}$ & Arctic & NOAA-ESRL-GMD & $\mathrm{EBC}$ & PSAP & 2001-2008 \\
\hline Southern Great Plains & $97.5^{\circ} \mathrm{W}$ & $36.6^{\circ} \mathrm{N}$ & $315 \mathrm{~m}$ & Continental & NOAA-ESRL-GMD & $\mathrm{EBC}$ & PSAP & 2001-2008 \\
\hline Trinidad Head & $124.1^{\circ} \mathrm{W}$ & $41.1^{\circ} \mathrm{N}$ & $107 \mathrm{~m}$ & Marine & NOAA-ESRL-GMD & $\mathrm{EBC}$ & PSAP & $2002-2008$ \\
\hline Mauna Loa & $155.6^{\circ} \mathrm{W}$ & $19.5^{\circ} \mathrm{N}$ & $3397 \mathrm{~m}$ & Marine, free troposphere & NOAA-ESRL-GMD & $\mathrm{EBC}$ & PSAP & 2001-2008 \\
\hline Bondville & $88.4^{\circ} \mathrm{W}$ & $40.05^{\circ} \mathrm{N}$ & $230 \mathrm{~m}$ & Continental & NOAA-ESRL-GMD & EBC & PSAP & 2001-2008 \\
\hline Birkenes & $8.25^{\circ} \mathrm{E}$ & $58.4^{\circ} \mathrm{N}$ & $190 \mathrm{~m}$ & Continental & EMEP & $\mathrm{EC}$ & $\begin{array}{l}\text { Thermal-optical } \\
\text { methods (Sunset Lab.) }\end{array}$ & 2001-2007 \\
\hline Melpitz & $12.9^{\circ} \mathrm{E}$ & $51.5^{\circ} \mathrm{N}$ & $86 \mathrm{~m}$ & Continental & EMEP & $\mathrm{EC}$ & $\begin{array}{l}\text { Thermal methods } \\
\text { (VDI 2465) }\end{array}$ & 2004-2007 \\
\hline Montseny & $2.35^{\circ} \mathrm{E}$ & $41.76^{\circ} \mathrm{N}$ & $700 \mathrm{~m}$ & Continental & EMEP & $\mathrm{EC}$ & $\begin{array}{l}\text { Thermal-optical } \\
\text { methods (Sunset Lab.) }\end{array}$ & 2002-2008 \\
\hline
\end{tabular}

* PSAP: Particle Soot Absorption Photometer.

reach the surface in the Arctic regions and remain at higher altitudes (Stohl, 2006). However, Schwarz et al. (2010) did not find an increase by altitude between 60 to $80^{\circ} \mathrm{N}$ in January 2009 from flight measurements done in the Pacific. Figure $2 \mathrm{~d}$ shows modelled spring concentrations of $\mathrm{BC}$ in surface snow, which will be covered in the next section.

In Fig. 3 observed monthly concentrations of $\mathrm{BC}$ at several sites (Table 3) are compared with the corresponding model results for the same month and year for the period 2001 to 2008, when observations are available. The solid lines show a one-to-one relationship. The dotted lines show a factor of 2 difference and the dashed lines a factor 10 difference between the observations and modelled concentrations of BC. Note again that the observations are given as EBC for optical measurements or EC for thermo-optical measurements.

Figure 3a compares the observed and modelled monthly concentrations at Zeppelin station at $78.9^{\circ} \mathrm{N}$. For the winter months, December to February, the model simulates fairly well. For the spring months (March, April and May) however, the model underestimates the concentrations. The model captures to some extent the pollution episode in AprilMay 2006 (Stohl et al., 2007), shown as the uppermost cross to the right in Fig. 3a, although not as high concentrations as observed. This was an episode related to biomass burning, primarily agricultural waste burning, in Eastern Europe, and for the modelling we use monthly mean emission data for biomass burning. This may be one reason for the underestimation of the concentration of this episode, or that the emission estimates for this agricultural burning may be underestimated in the GFED data. Another Arctic station is Barrow on the northern shore of Alaska. At this site, the model generally underestimates the concentrations of BC except for some summer months where biomass burning episodes enhanced the concentrations in the model results (Fig. 3b). These biomass burning episodes are not seen in the observation data, indicating that not as much of the $\mathrm{BC}$ from biomass burning events reach the surface layer as seen in the model results. The largest underestimation in the model is found for October to April, when the observed values are highest. Hirdman et al. (2010) showed that sources in Eurasia are important for Barrow. There might be problems with cross polar transport in the model.

For Southern Great Plains the variability in the observed monthly concentrations is greater than in the model result (Fig. 3c). The site is located in flat terrain and has many local sources of $\mathrm{BC}$ in its surroundings, including the Oklahoma City $100 \mathrm{~km}$ to the south and oil refineries at Ponca City $35 \mathrm{~km}$ to the east. The seasonal pattern is not captured in the model. The model gives highest concentrations during winter, while in the observations the concentrations are highest during summer.

At Trinidad Head, a remote coastal site north in California, the model results have a similar spread as in the observations, but we generally underestimate the concentrations. The seasonal observed pattern, with highest concentrations in autumn, is captured by the model. For some biomass burning episodes in June-September, the model results are too high (Fig. 3d).

The observation site at Mauna Loa is located at $3397 \mathrm{~m}$ altitude on the island of Hawaii, a topography not captured by the model. In the model the concentration is very dependent on height. The modelled marine boundary layer has low concentrations of $\mathrm{BC}$ due to removal processes, while there are higher concentrations aloft followed by a decrease in the concentration by height. In the observed data, the times of the day that experience air from lower altitudes are excluded, and we compared these observations with the model level corresponding to the altitude of the observatory. The modelled concentrations match the observations fairly well (Fig. 3e), except for low observed concentrations where the model is over predicting. The seasonal pattern with highest concentrations during spring is captured by the model.

Bondville is a rural site, $200 \mathrm{~km}$ south of Chicago. The concentration level is reasonably captured by the model 

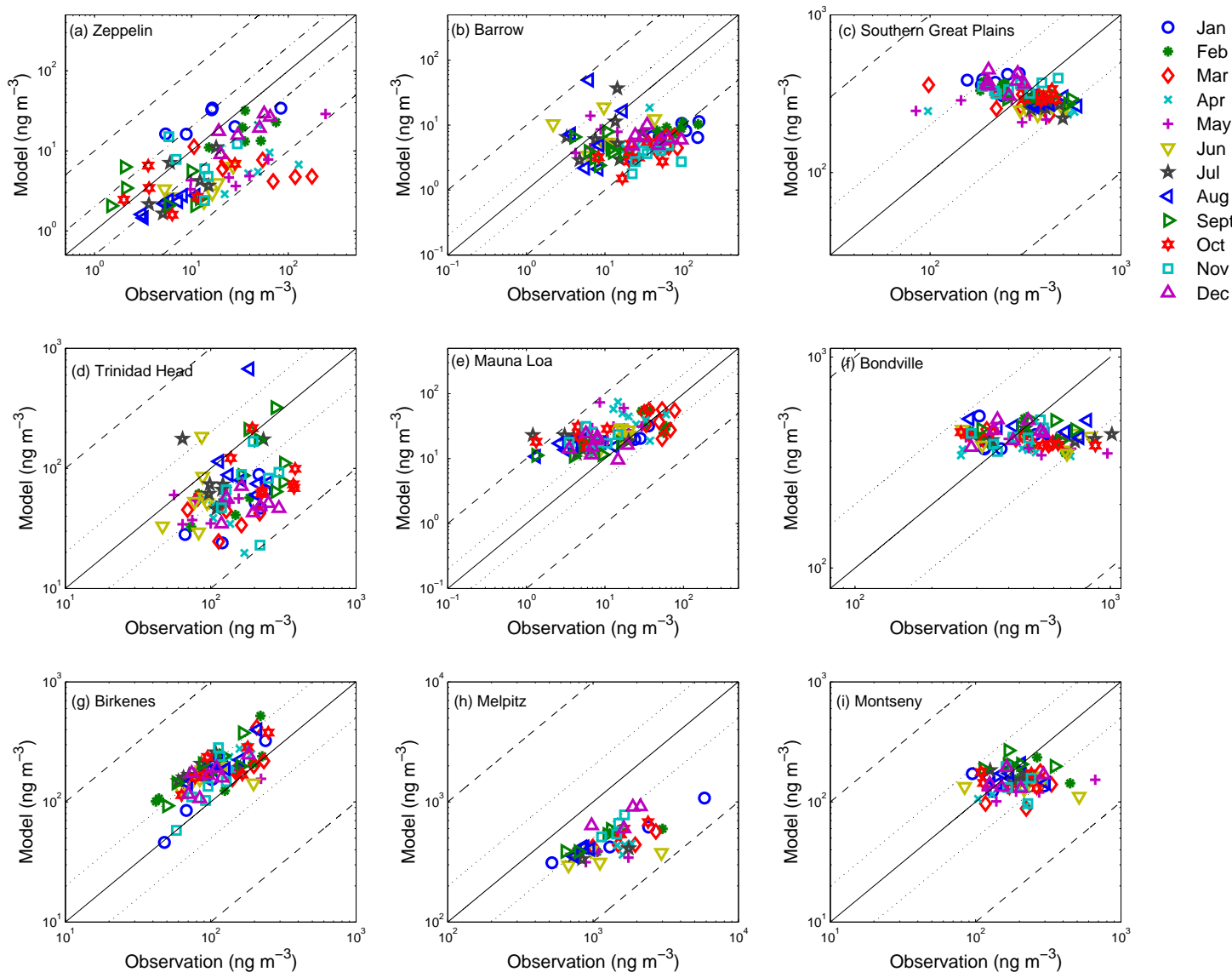

Fig. 3. Scatter plots of monthly averaged concentration of EBC or EC from observations at various sites and corresponding model results of BC concentrations for the same months and years. The solid line shows a one-to-one correspondence. The dotted lines show a factor of 2 difference and the dashed lines a factor 10 difference between the observations and model results. The comparison is shown for Zeppelin (a), Barrow (b), Southern Great Plains (c), Trinidad Head (d), Mauna Loa (e), Bondville (f), Birkenes (g), Melpitz (h) and Montseny (i).

(Fig. 3f), and no clear seasonal cycle is seen in the observed concentrations. The spread in the observations is larger than in the model, which may be attributed to the location of the site in a grid box with large emissions. This would lead to large gradients in $\mathrm{BC}$ concentrations both horizontally within the grid box not resolved by the model and between the surface layer and the model layers above.

At Birkenes, the model overestimates the concentration compared to the observations for all seasons by up to a factor of 2 (Fig. 3g). Birkenes is an EMEP (European Monitoring and Evaluation Programme) station located in a rural area of southern Norway, approximately $20 \mathrm{~km}$ from the Skagerrak coast, well suited for monitoring the outflow of air pollution from the European continent (EMEP, 2010). A regional EMEP model study (Tsyro et al., 2007) also overestimated the EC concentration at this station and suggested that local emission from residential combustion may be overestimated. The model under-predicts the BC concentration compared to the observations (Fig. 3h) at the Melpitz EMEP station. Melpitz is a rural polluted site in an agricultural region about
$40 \mathrm{~km}$ north east of Leipzig, Germany. However, the separation of $\mathrm{OC} / \mathrm{EC}$ for the measurement at this station, does not take into account charring of $\mathrm{OC}$, and is therefore known to greatly overestimate the EC concentration (EMEP, 2010). A third EMEP station is Montseny, which is a mountain station in a National Park in Spain. Montseny is located far from any local source of pollution and the air is representative of the regional background. The model reproduces the data reasonably well, although the model underestimates during high concentration episodes.

At Bondville and Southern Great Plains, routine measurements of light absorption have been made from small aircraft several times a week during daytime. Light absorption was measured by a PSAP and converted to EBC concentration by multiplying with a mass absorption efficiency of $9.7 \mathrm{~m}^{2} \mathrm{~g}^{-1}$ (Bond and Bergstrom, 2006), as was used for the surface data. Description of the flight measurements can be found in (Andrews et al., 2004, 2011). The measurements are for the years 2006-2008 at Bondville (BND) and 2001 to 2007 at Southern Great Plains (SGP). The comparisons between 
(a) SGP winter

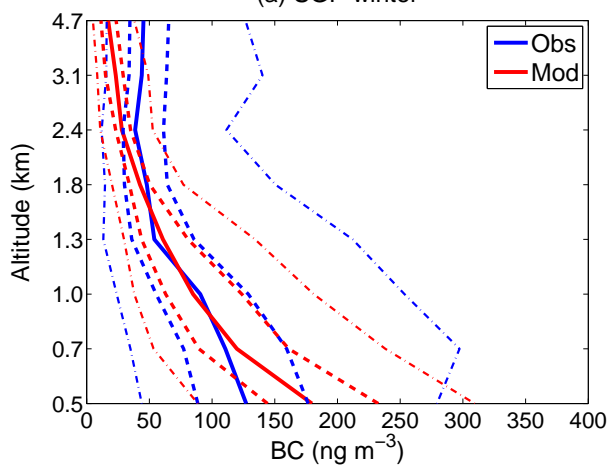

(c) SGP summer

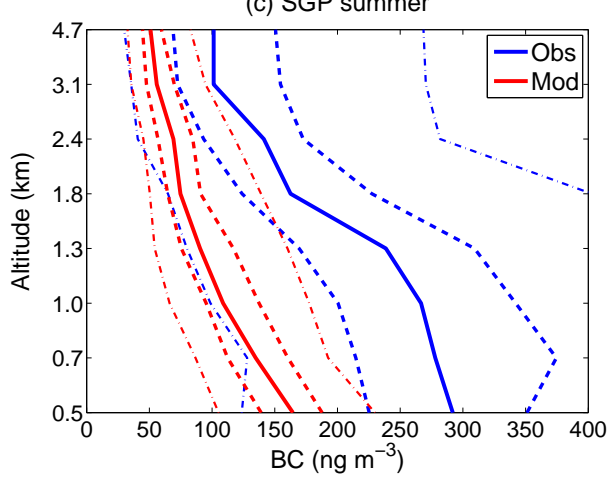

(b) SGP spring

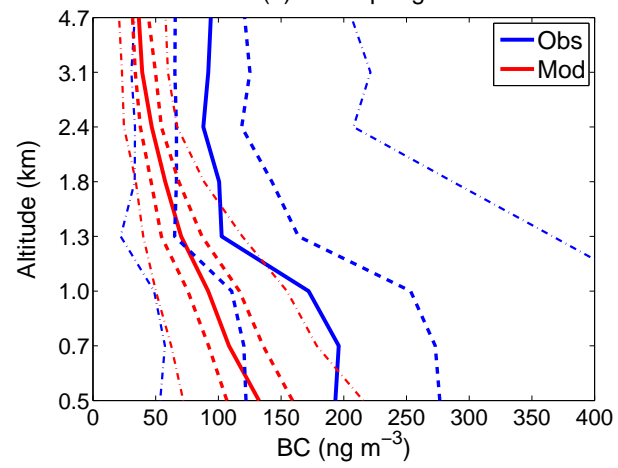

(d) SGP autumn

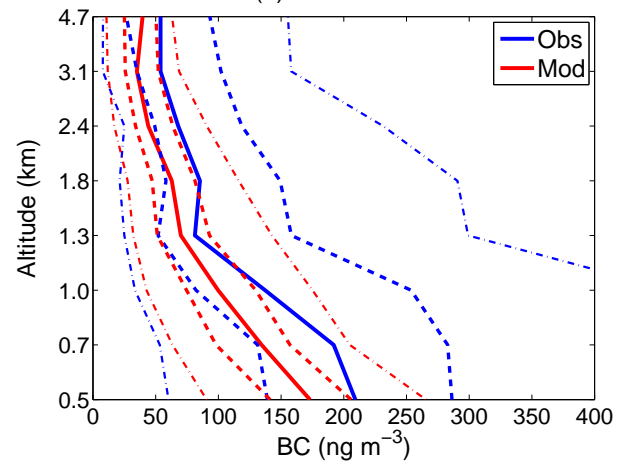

Fig. 4. Observed EBC concentrations by altitude from flight observations (red) at Southern Great Plains (SGP) and corresponding model results of BC concentrations (blue). The median (solid line), 32 and 68 percentiles (dashed) and 10 and 90 percentiles (dash-dotted). Each season is plotted separately.

the observations and the corresponding model results of $\mathrm{BC}$ for the 4 seasons are shown in Figs. 4 and 5. Generally, we see that the spread in the observations is larger than in the model results, due to the coarse grid in the model and the use of monthly mean emissions, which will average out the modelled concentrations. For SGP, the median of the observations is lower than the median of the model results in the lowest layers during winter, but they follow each other more closely at higher altitudes (Fig. 4a). For the rest of the year, the model underestimates the observations at all altitudes, with the greatest underestimation being a factor of 2 during summer (Fig. 4c). At BND, the model underestimates in the lowest layers while giving a better agreement aloft for all seasons. Largest disagreements are found for the summer months when the model underestimates by a factor of 2.5 near the surface (Fig. 5c). At 1-2 km aloft, the model overestimates during winter (Fig. 5a), underestimates during spring (Fig. 5b) and shows a better agreement during autumn (Fig. 5d).

Koch et al. (2009b) compared the AeroCom model results with vertical profiles of BC obtained by flight campaigns. Figure 6a compares our model results and profiles obtained by flight campaigns in tropics and mid-latitudes, while Fig. 6b compares our model results and profiles from high latitudes. These observations are the same as plotted in Fig. 9 and 10 in Koch et al. (2009b). The details of the observed profile data are given in Koch et al. (2009b). For the cases where significant biomass smoke was encountered, we plot the median instead of the mean of the observations (Figs. 9d, 10d and 10e in Koch et al., 2009), and for the ARCPAC campaign that had heavy smoke conditions we plot the mean for the flight that was most representative of background conditions (Fig. 10c in Koch et al., 2009). At high latitudes (Fig. 6b) the modelled concentrations increase with height to a certain level before the concentrations decline, except for one of the summer campaigns where concentrations in the lowest layers were the highest. The level with highest concentrations in the model tends to be at a greater altitude than in the observations. In summer, the observations show a maximum concentration at low latitudes $(800-900 \mathrm{hPa})$ while for the observations during spring, the peak in observed concentrations is around $500-600 \mathrm{hPa}$. This may indicate that the model is missing emissions related to biomass burning during spring. In the tropics and at mid-latitudes the 
(a) BND winter

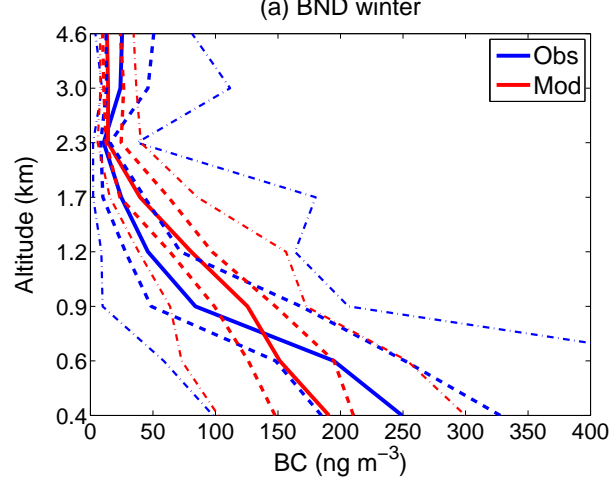

(c) BND summer

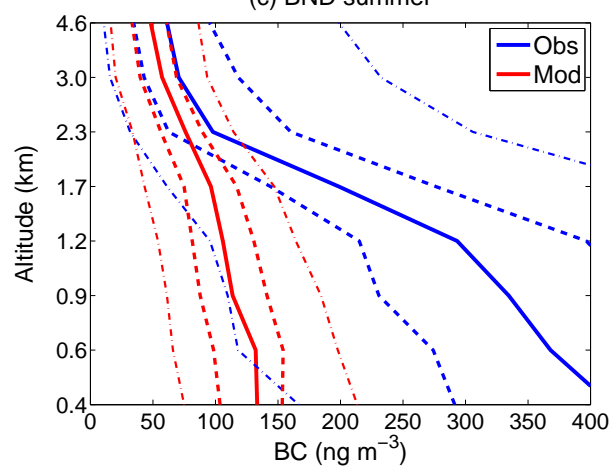

(b) BND spring

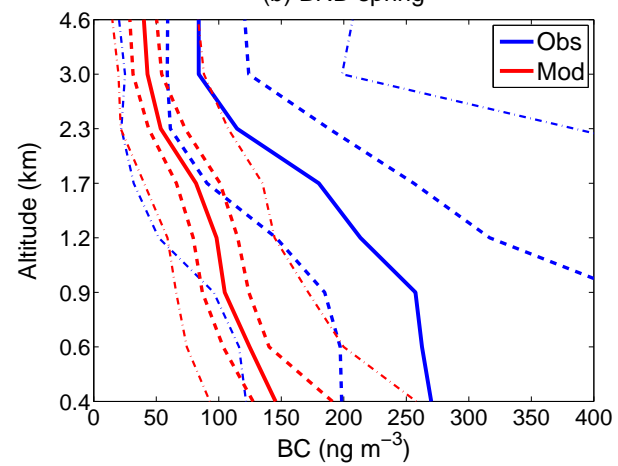

(d) BND autumn

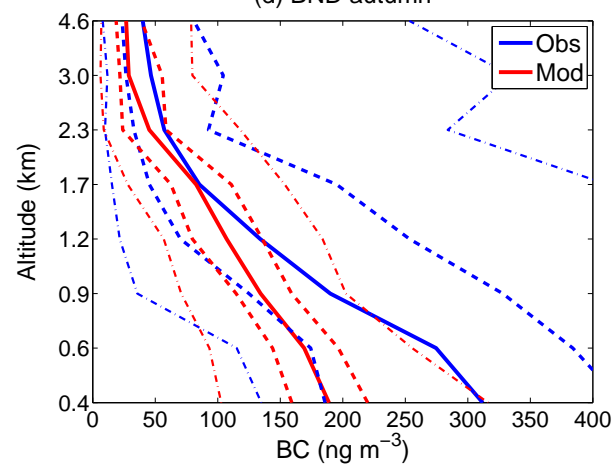

Fig. 5. Same as Fig. 4 but for Bondville (BND).
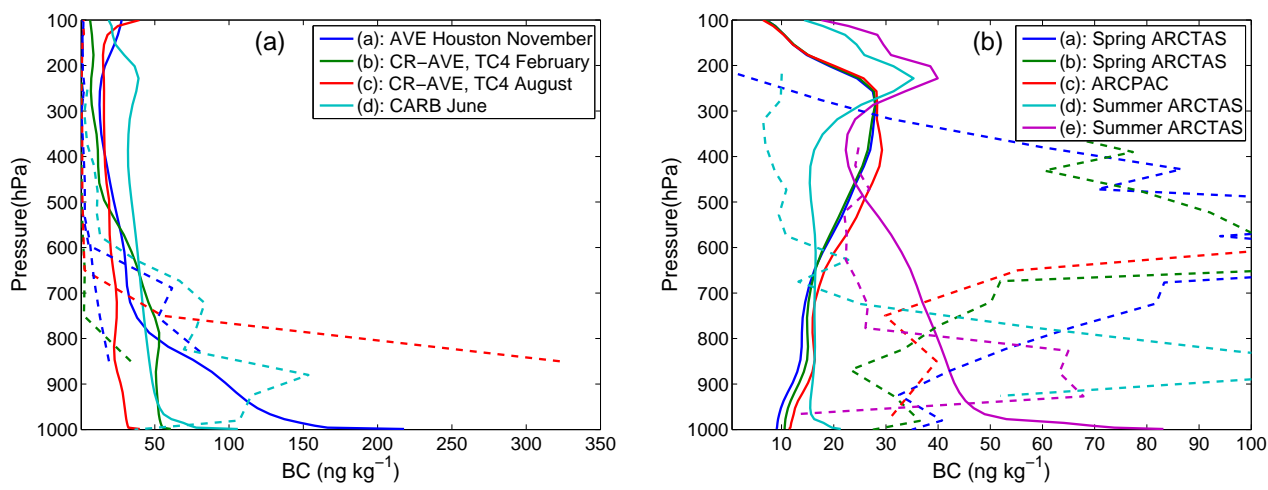

Fig. 6. Observed concentrations of $\mathrm{BC}$ by altitude from flight campaigns in tropics and mid latitudes (a) and at high latitudes (b). The figures (a) and (b) correspond to figure 9 and figure 10 in Koch et al. (2009) respectively. The corresponding model results (solid lines) and observation means or medians (dashed) are plotted with the same colour.

model also tends to overestimate at high altitudes (Fig. 6a). This is also found in Koch et al. (2009b) when comparing the profile data with the modelled BC profiles from the AeroCom models.

Figure 7 compares measurements of $\mathrm{BC}$ from a flight campaign from $67^{\circ} \mathrm{S}$ to $80^{\circ} \mathrm{N}$ in the Pacific in January 2009 (Schwarz et al., 2010) with profiles corresponding to the flight track from the modelled monthly mean BC concentrations for the years 2001 to 2008. The model overestimates the mean observed $\mathrm{BC}$ at all latitudes and altitudes, except close to the surface at high northern latitudes. As in Fig. 6, the model over predicts in the upper troposphere, especially in the tropics (Fig. 7c) where the large gradient between 600 and $400 \mathrm{hPa}$ is not captured by the model. Compared to the 

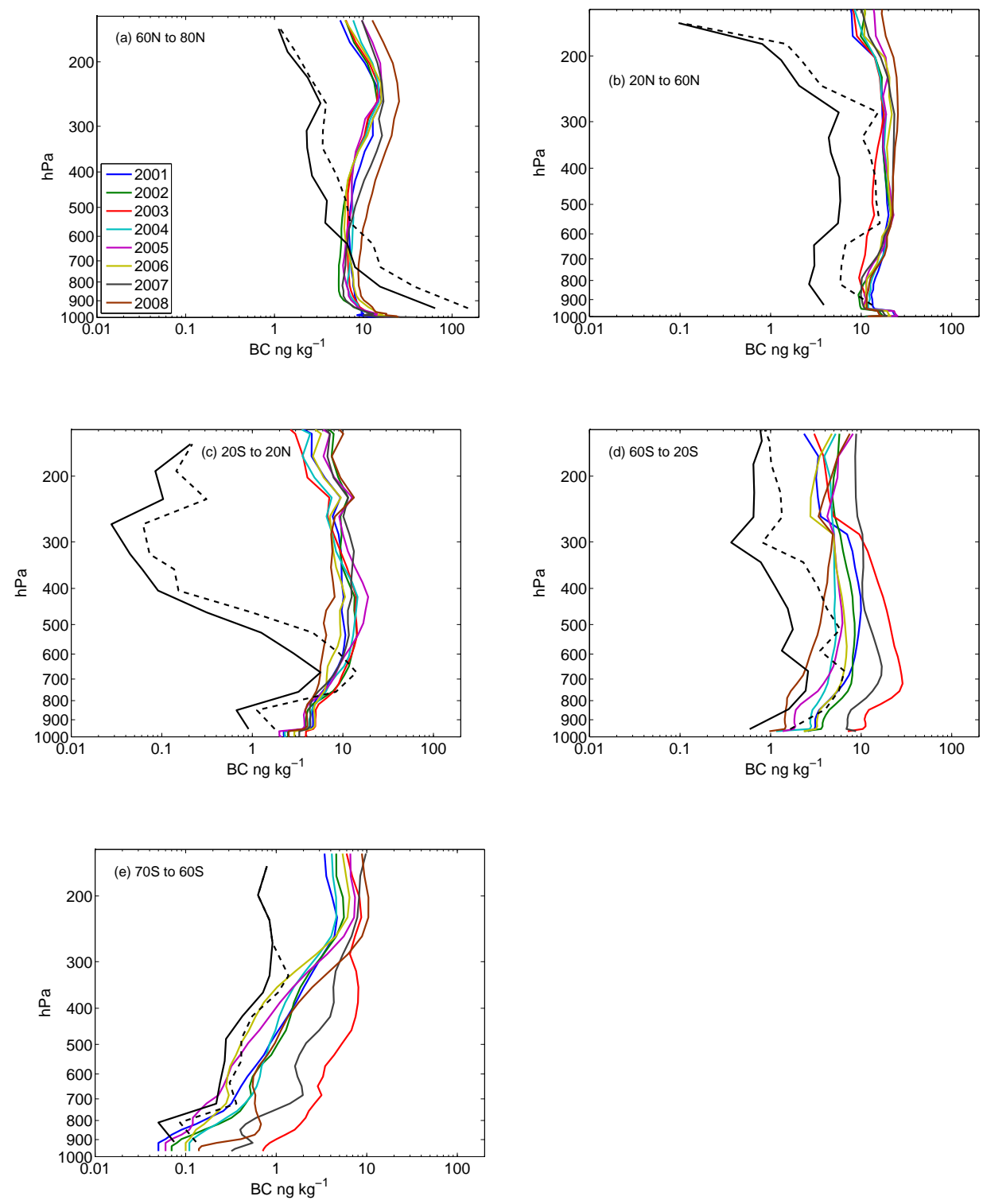

Fig. 7. The average vertical profile of BC observed in each latitude zone from Schwarz et al. (2010) (black line) and dashed line indicating the standard deviation of the observations. The coloured lines show the corresponding vertical profiles from the modelled monthly mean corresponding to the flight track, one line for each of the simulated years 2001 to 2008.

AeroCom model results Schwarz et al. (2010) found that the models greatly overestimate in this region as well, and related this to insufficient wet removal in the models and of minor importance errors in advection processes. Koch et al. (2009) also related the discrepancies between models and aircraft measurements to removal processes being to low and also vertical mixing may be too excessive. We should note that in Fig. 7 the averaged January mean concentration is compared with an observed snap shot of the concentration.

\subsection{Black carbon in snow, 2000-2008}

The concentrations of $\mathrm{BC}$ in snow depend on the deposited $\mathrm{BC}$ in snow, total precipitation, snow depth and how the $\mathrm{BC}$ particles are redistributed as the snow melts. Figure $2 \mathrm{~d}$ shows modelled concentrations of BC in surface snow (uppermost $5 \mathrm{~cm}$ or less) for spring months March, April and May (MAM), which is the most intense period for snow melt. The highest concentrations are found at low latitudes where the snow depths are thin due to melting and where most of the $\mathrm{BC}$ sources are. In snow on the Arctic sea ice the concentration is mostly between 2 and $10 \mathrm{ng} \mathrm{g}^{-1}$. 

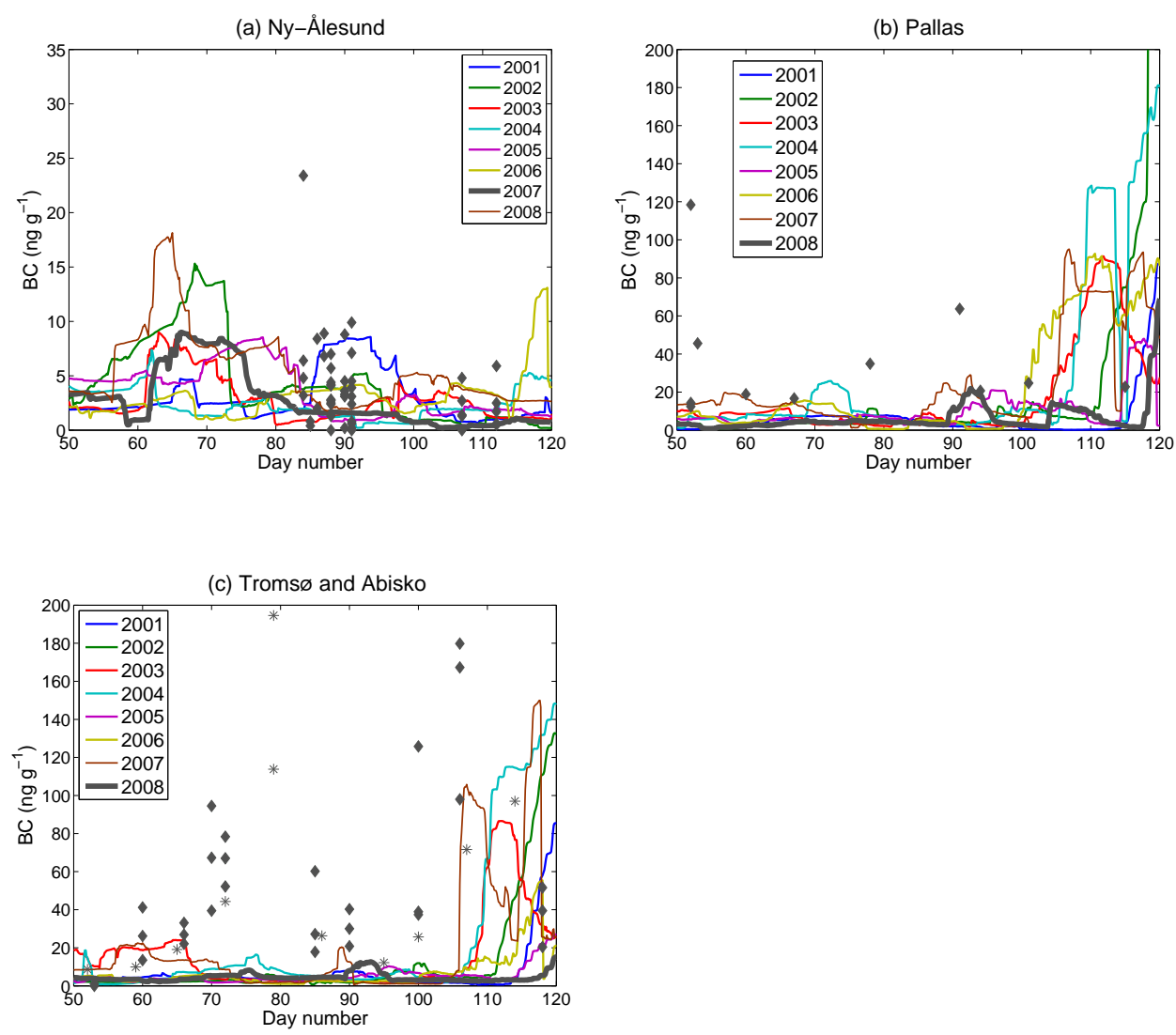

Fig. 8. Observed concentrations of $\mathrm{BC}$ in $5 \mathrm{~cm}$ surface snow at (a) Ny-Ålesund, (b) Pallas and (c) Tromsø (diamonds) and Abisko (stars) and the modelled concentration of $\mathrm{BC}$ in the uppermost $5 \mathrm{~cm}$ of the snowpack for the spring period at the same location. The modelled concentrations in the year corresponding to the year of the observations are plotted with a thick line.

During the years 2006-2008, the Norwegian Polar Institute carried out several field campaigns for measuring elemental carbon in snow in the Arctic regions (Forsström et al., 2009). Samples of the uppermost $5 \mathrm{~cm}$ of the snow were collected, brought to the lab frozen, and then quickly melted in a microwave oven. The melt water was filtered on a quartz microfiber substrate, and the filters were analyzed with a thermo-optical method as described in Forsström et al. (2009).

A few of the sampling locations were close to Ny Ålesund and the Zeppelin observatory $\left(11.9^{\circ} \mathrm{E}, 78.9^{\circ} \mathrm{N}\right)$. Ny-Ålesund is a small community with $40-150$ inhabitants and few local sources of BC. Figure 8a shows the modelled concentration of $\mathrm{BC}$ in snow in the upper $5 \mathrm{~cm}$ of the snowpack for the years 2001-2008 compared to the $5 \mathrm{~cm}$ surface samples close to Ny-Ålesund in spring 2007. The figure shows the spring period from 19 February (day number 50) until 30 April (day number 120). There is a large spread in the measurements, but the model results for year 2007 fall within the range of the measurements.

In 2008 measurements were done close to Barrow, on the northern shore of Alaska $\left(156.6^{\circ} \mathrm{W}, 71.3^{\circ} \mathrm{N}\right)$. Unfortunately the snow depth in the Oslo CTM2 is too shallow in that area, leading to unrealistically high concentrations (Fig. 2d). The measured concentrations in April 2008 were in the range 0 $15 \mathrm{ng} \mathrm{g}^{-1}$, which corresponds reasonably well with the modelled concentrations in grid boxes around the coast line of Alaska with realistic snow depth.

Measurements were also performed in Pallas, Finland $\left(24.1^{\circ} \mathrm{E}, 68.0^{\circ} \mathrm{N}\right)$, Troms $\varnothing$, Norway $\left(18.9^{\circ} \mathrm{E}, 69.7^{\circ} \mathrm{N}\right)$ and Abisko, Sweden $\left(18.3^{\circ} \mathrm{E}, 68.3^{\circ} \mathrm{N}\right)$ during spring 2008 . The sampling site in Troms $\emptyset$ was conducted within the city with relatively high levels of $\mathrm{BC}$ in the air. Abisko and Pallas are less affected by local sources, but the differences in precipitation amounts leads to different concentration levels in the snow. The precipitation amounts in Abisko and Pallas are around $300 \mathrm{~mm} \mathrm{yr}^{-1}$ and $500 \mathrm{~mm} \mathrm{yr}^{-1}$, respectively. In Troms $\varnothing$, which is close to the coast of the North Atlantic, the precipitation during the sampling period (February-May) was as much as $356 \mathrm{~mm}$. In Fig. 8b the measured and modelled concentration at Pallas are plotted. The model underestimates the concentrations of BC in snow at this site. Troms $\varnothing$ and Abisko are located in the same model grid box, so these observations are plotted together with the model results in 
Fig. 8c. Also for these two sites the model underestimates the $\mathrm{BC}$ concentration in snow. The observed concentrations of BC in Abisko and Troms $\varnothing$ are of similar magnitude, although snow from Abisko is assumed to be cleaner than snow from Troms $\varnothing$. This may be explained by the large difference in the precipitation amount between Abisko and Troms $\varnothing$.

From these figures comparing observation and modelled $\mathrm{BC}$ concentrations in snow, we can see that at all sites except Ny-Ålesund the modelled concentration of $\mathrm{BC}$ in snow rises at the end of April. This is due to melting of the snow pack and the assumption that the $\mathrm{BC}$ remains at the surface when the snow pack melts. The removal of $\mathrm{BC}$ with melt water is discussed in Flanner et al. (2007). That BC remains at the surface is based on the assumption that hydrophilic BC particles remain at the surface due to their size and also that observations of mineral particles show this behaviour. This is also seen in observations of BC in snow packs (Aamaas et al., 2011), with enhanced concentrations when the snow melts. For the modelled concentrations at Ny-Ålesund the melting and corresponding concentration increase occur later in the spring than the period shown in Fig. 8.

Doherty et al. (2010) published measurements of BC in snow done during 2005 to 2009 in the Arctic region applying an improved optical method as described in Grenfell et al. (2010). The regional median and/or mean of their springtime observations are plotted together with modelled regional median of the springtime $\mathrm{BC}$ concentrations in surface snow for the period 2001-2008 (Fig. 9). The model captures the BC concentration fairly well. However, disagreements are seen for the western and eastern Russia and the Canadian subarctic region, where the model underestimate the observed concentrations. In eastern Russia, measurements were done at only four sites, and therefore only the mean value was reported, which was five times higher than the modelled mean regional concentration. The uncertainty range in western Russia is large $\left(34 \pm 46 \mathrm{ng} \mathrm{g}^{-1}\right)$, with mean and median well above the modelled regional values. As can be seen in Fig. $2 d$ there are spatial variations in the modelled BC surface concentrations in the regions summarized in Fig. 9. A detailed comparison using the modelled daily concentrations corresponding to each of the observations presented in Doherty et al. (2010) would be useful.

Using the available emission inventories, the modelled burden of $\mathrm{BC}$ in snow north of $65^{\circ} \mathrm{N}$ at the end of April, shows much larger values for FFBF BC than BB BC (Table 2). For the months January to April, 4-12\% of the total $\mathrm{BC}$ in snow north of $65^{\circ} \mathrm{N}$ originates from open biomass burning. This seems to be in disagreement with the results from Hegg et al. (2009, 2010), who did source attribution of BC in snow samples collected during 2007-2009 using positive matrix factorization. Their analysis indicates that most of the BC in the snow samples had a biomass source. It may be that part of the discrepancy is because large contributions from residential wood burning (included in our FFBC source) were interpreted as open biomass burning as they

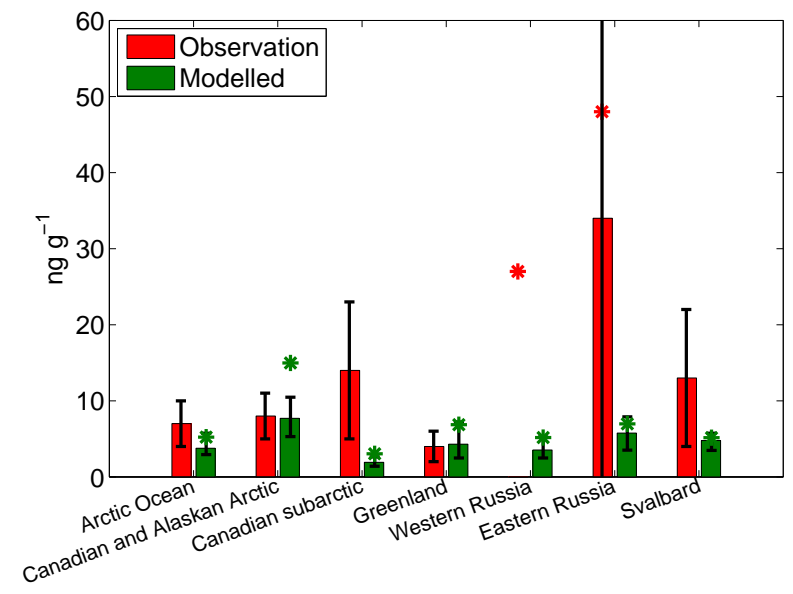

Fig. 9. Observed springtime $\mathrm{BC}$ concentration in surface snow given for seven different regions as median (red bars \pm 1 standard deviation) and/or mean values (red stars) (Doherty et al., 2010, Table 2 ) and modelled median (green bars \pm 1 standard deviation) of the spatial and annual variability (2001-2008) in monthly mean surface snow BC concentrations for the spring months (MAM) and spring mean (green stars) for the same seven regions.

have similar source signatures. A recent study by Yttri et al. (2011) investigated the source of elemental carbon in the atmosphere measured at Nordic rural sites in late summer using ${ }^{14} \mathrm{C} /{ }^{12} \mathrm{C}$ ratio. They found however that fossil fuel totally dominated the ambient elemental carbon loadings.

\subsection{Black carbon in the atmosphere, $1750-2000$}

Figure 10a shows the zonal distribution of the atmospheric load for the years 1750 until 2000 for total BC and Fig. 10b for FFBF BC only. The total atmospheric burden of FFBF $\mathrm{BC}$ has increased from pre-industrial times until present, although north of $65^{\circ} \mathrm{N}$ the burden has decreased since 1960 (Fig. 10c and Table 2) due to the reduction in the emissions in Europe and North America. For BB BC, the global burden was $50 \mathrm{Gg}$ in 1900 and $65 \mathrm{Gg}$ in 2000 . For the years in the middle of the century, the global burden was slightly lower than at the beginning and end of the 20th century (Fig. 10d and Table 2). For the BB BC north of $65^{\circ} \mathrm{N}$, the burden in the middle of the century was less than half of the burden in $1900(0.8 \mathrm{Gg})$ and $2000(0.7 \mathrm{Gg})$.

There are few direct long-time measurements of $\mathrm{BC}$ in the atmosphere available to compare with the model. The observed annual mean BC concentration at Barrow decreased by $27 \%\left(19 \%\right.$ decade $\left.^{-1}\right)$ from 1989 to 2003 , while at Alert (Arctic Canada) the decrease was $54 \%\left(38 \%\right.$ decade $\left.^{-1}\right)$ (Sharma et al., 2006). In contrast, the model shows a BC increase by $4 \%$ from 1990 to 2000 at Barrow. This is due to an increase in the concentration in the summer months associated with open biomass burning, however the observations did not show any clear trend for the summer months at 

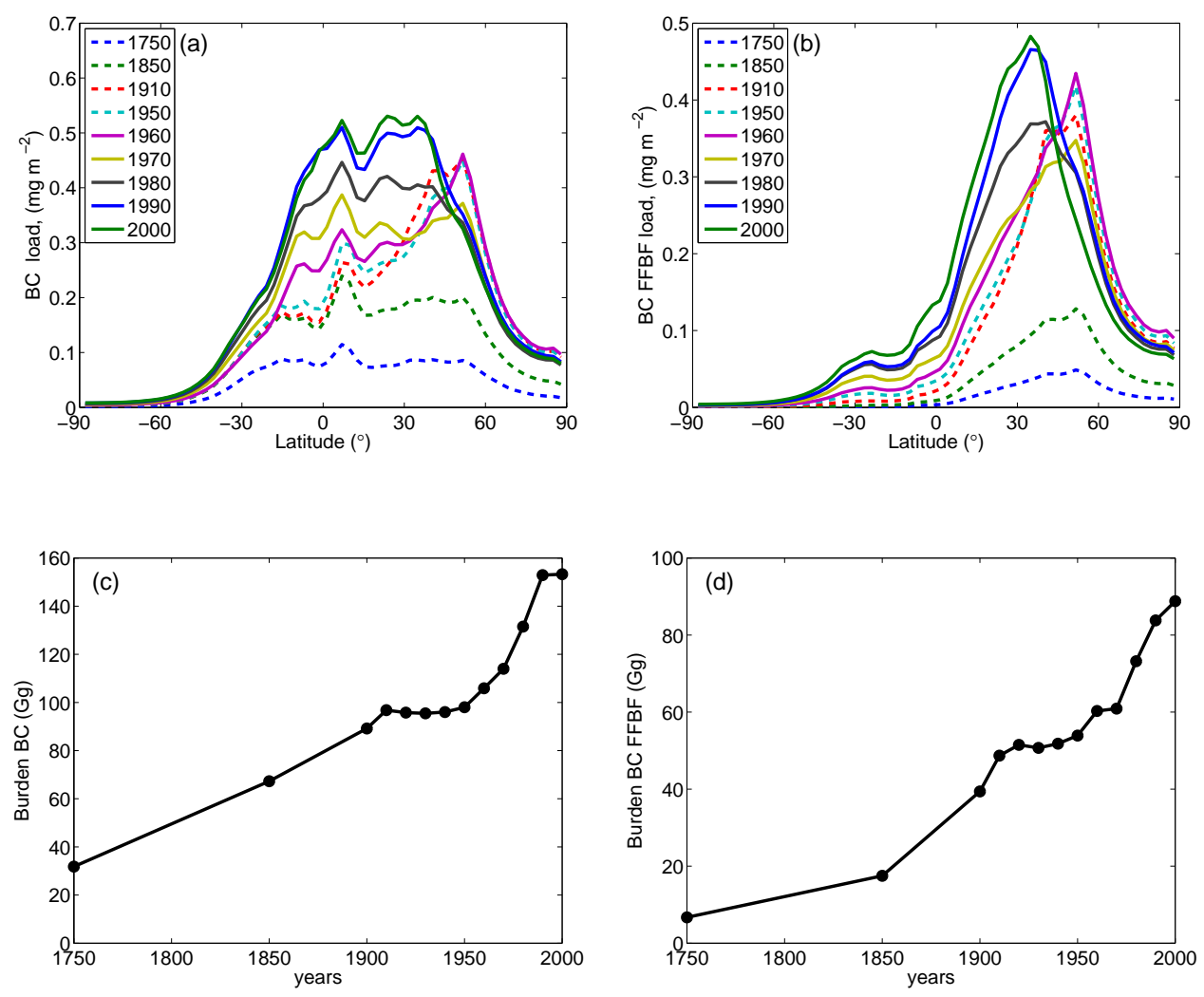

Fig. 10. Modelled zonal distributions of the atmospheric load of BC for selected years between 1750 until 2000 for total BC (a) and fossil fuel and biofuel BC (b). Historical development of total BC burden (c) and fossil fuel and biofuel BC (d).

Barrow. At Alert, the modelled annual mean concentrations of BC decreased by $16 \%$ from 1990 to 2000 . At both sites, a downward trend in winter is seen in both the model and observations. The winter observations showed a decrease of $49 \%\left(35 \%\right.$ decade $\left.^{-1}\right)$ at Alert and $33 \%\left(24 \%\right.$ decade $\left.^{-1}\right)$ at Barrow from 1989 to 2003, while the monthly modelled concentrations in January decreased by $25 \%$ at Alert and $30 \%$ at Barrow from 1990 to 2000.

For longer time series the model results can be compared to $\mathrm{BC}$ derived from ice cores (see next section) or sediment cores. Husain et al. (2008) published results from a sediment core in West Pine Pond near Whiteface Mountain $\left(73.9^{\circ} \mathrm{W}\right.$, $\left.44.4^{\circ} \mathrm{N}\right)$. Figure 11a compare the annual concentration derived from the sediment core and the model results. In 1850 , the modelled concentration was higher than the atmospheric concentration inferred from the measured BC concentrations in the sediments. Both the model and the measurements show a rapid increase in the BC concentrations until the 1920s, although the observations have a more rapid increase. The model shows a decrease until the 1970s and stable concentrations thereafter, while the measurements indicate that concentrations were fairly constant until 1980 and then rapidly decreased. The relative differences between the model and the measurements might be due to shortcomings in the emission data, variability in atmospheric transport or scavenging efficiencies that is not included in the model, or uncertainties in the derived atmospheric BC concentrations. In Fig. $11 \mathrm{~b}$ the modelled annual concentrations during the last eight years are shown together with atmospheric BC inferred from the sediment core and from direct measurements from 1990 to 2008 at Whiteface Mountain (Husain et al., 2008). The year to year variability for the modelled BC concentration at this site using the results from the 2001-2008 simulations is too small to explain the differences between the modelled and observed concentration changes.

\subsection{Black carbon in snow, 1750-2000}

The development of modelled BC concentrations in snow for the spring months (March, April and May) are plotted in Fig. 12a-d. Figure 12d shows the time evolution of mean $\mathrm{BC}$ concentration in spring in four different regions, from 1750 until 2000. From the model results the concentration in snow on the sea ice in the Arctic Ocean has decreased since 1960. At lower latitudes the concentrations in the European sector were greatest in 1960 followed by a sharp decrease until 2000. The concentration of BC in snow in North America showed no trend between 1900 and 2000. 

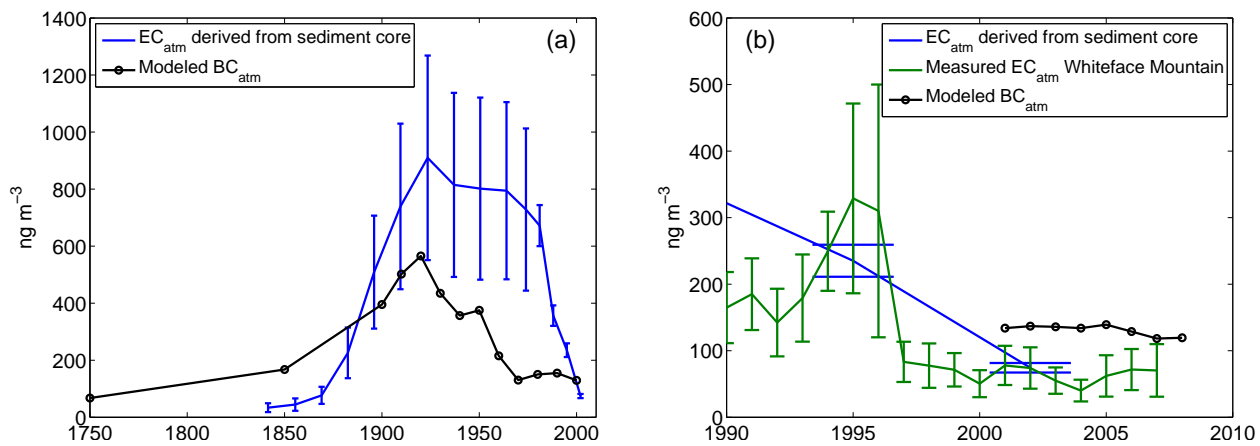

Fig. 11. Comparison of modelled annual mean $\mathrm{BC}$ concentrations with derived atmospheric EC concentrations from sediment core at West Pine Pond near Whiteface Mountain from Husain et al. (2008) (a). (b) Same as in (a) but for the time period 1990 to 2008 and with measured EC from filters at Whiteface Mountain from Husain et al. (2008).
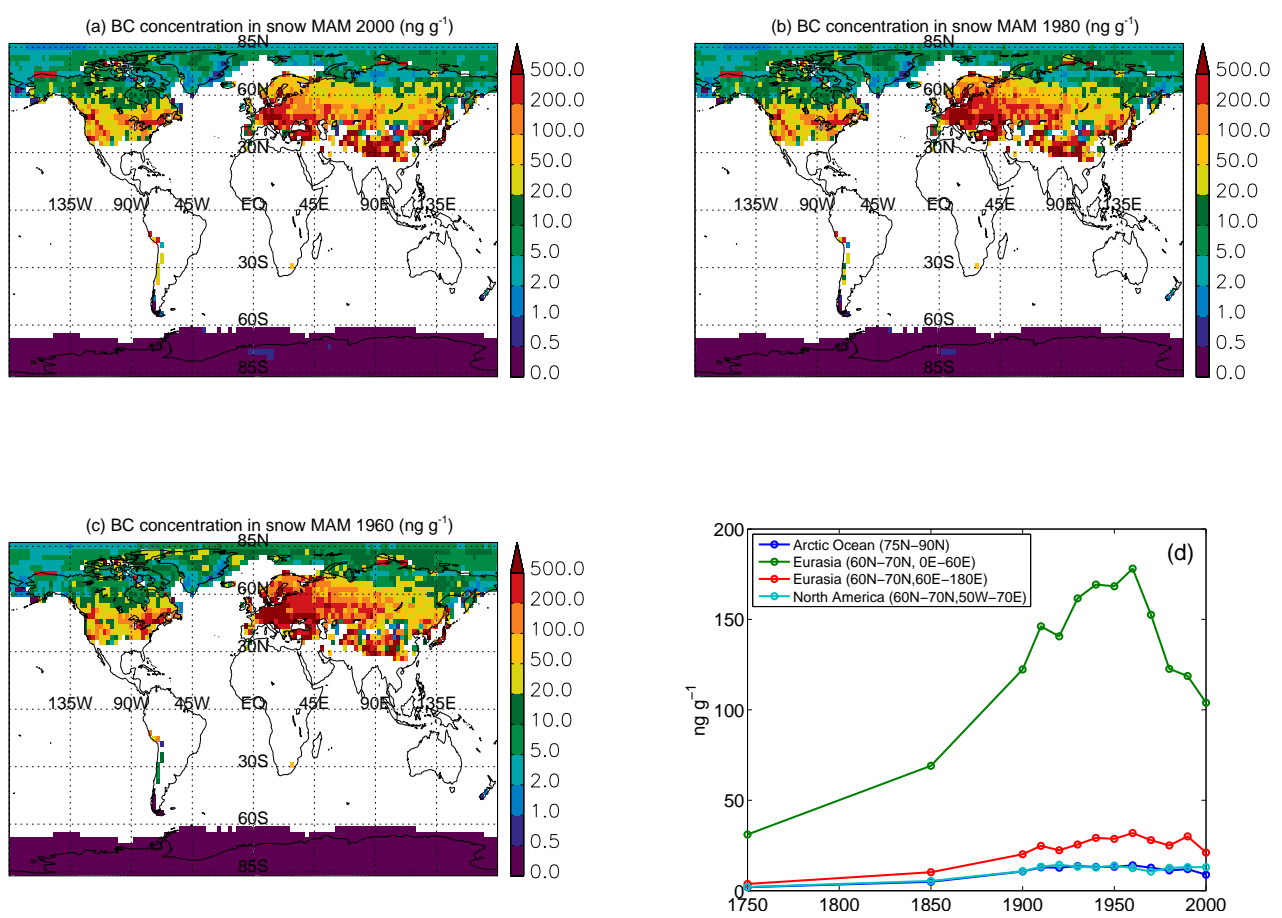

Fig. 12. Averaged concentration of $B C$ in surface snow (uppermost $5 \mathrm{~cm}$ ) for March, April and May (MAM) for the years 2000 (a), 1980 (b), 1960 (c) and the averaged MAM concentration in 4 different regions from 1850 until 2000.

During the 1980s several measurements of BC in snow were done both in Antarctica and in the Arctic. Warren and Clarke (1990) measured BC concentrations of 0.1$0.3 \mathrm{ng} \mathrm{g}^{-1}$ in snow close to the South Pole in 1986. From Fig. $12 \mathrm{~b}$ we see that the modelled concentrations of $\mathrm{BC}$ in snow in Antarctica are less than $0.5 \mathrm{ng} \mathrm{g}^{-1}$. Clarke and Noone (1985) made observations at several locations in the Arctic in 1983 and 1984. During spring the measured concentrations ranged from $7-60 \mathrm{ng} \mathrm{g}^{-1}$ for Barrow $\left(71.3^{\circ} \mathrm{N}\right.$, $\left.156.6^{\circ} \mathrm{W}\right), 7-52 \mathrm{ng} \mathrm{g}^{-1}$ at Spitsbergen $\left(79^{\circ} \mathrm{N}, 12^{\circ} \mathrm{E}\right), 4$ $9 \mathrm{ng} \mathrm{g}^{-1}$ at Greenland $\left(65.2^{\circ} \mathrm{N}, 43.8^{\circ} \mathrm{W}\right)$ and $9-77 \mathrm{ng} \mathrm{g}^{-1}$ in Abisko $\left(68.3^{\circ} \mathrm{N}, 18.5^{\circ} \mathrm{E}\right)$ as summarized in Flanner et al. (2007). If we compare these values with Fig. 12b, the modelled $\mathrm{BC}$ concentrations in snow for the spring months for the 1980s show reasonable agreement with the observations. In 1998, Grenfell et al. (2002) measured BC in snow on Arctic Ocean sea ice $\left(76^{\circ} \mathrm{N}, 165^{\circ} \mathrm{E}\right)$ with average values of $4-5 \mathrm{ng} \mathrm{g}^{-1}$, in good agreement with the model results presented in Fig. 12a. Due to differences in the measurement techniques used, both Forsström et al. (2009) and Doherty et al. (2010) could not definitively conclude that the concentrations in snow have decreased since the 1980s. 

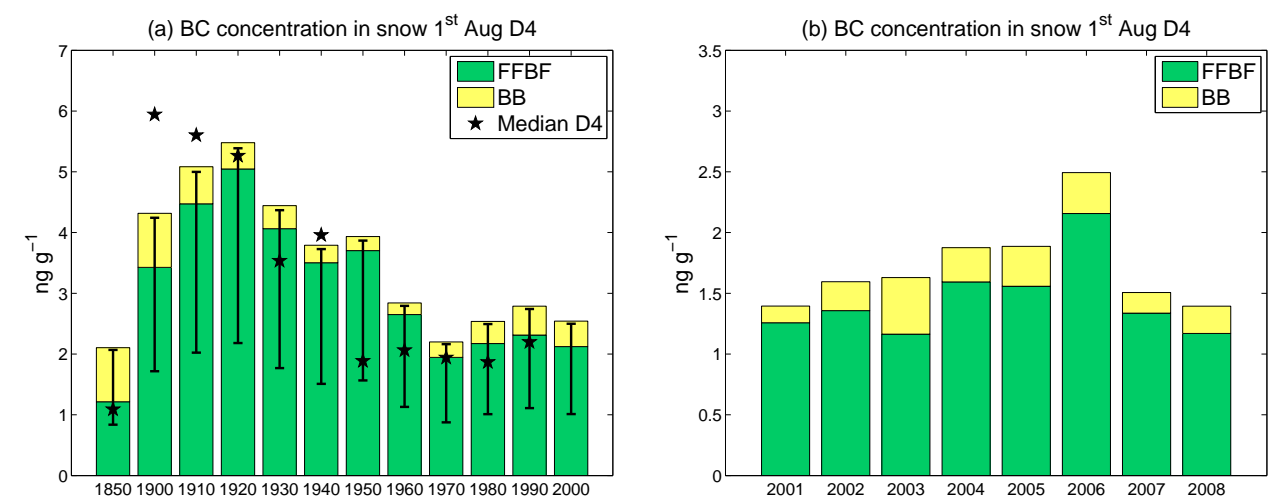

Fig. 13. Modelled annual concentrations of $B C$ in the snow at the location of the D4 ice core using 2006 meteorology. Contribution from biomass burning (yellow) and fossil fuel and biofuel (green). Error bars indicate two standard deviation around the mean of the modelled concentrations for the year 2001-2008 scaled to the historical concentrations assuming that the relative variability is constant in time. Decadal median of the BC concentration derived from the ice core (McConnell et al., 2007) is indicated by a star.

Data on BC concentrations in snow at Central Greenland since pre-industrial times are derived from two ice cores (McConnell et al., 2007; McConnell and Edwards, 2008). Both records show a maximum in the early 20th century followed by a decline, related to the emission trends in North America. Towards the end of the 20th century the BC concentrations were reduced by a factor of 2.5 and almost back to the pre-industrial concentrations in the $\mathrm{D} 4$ ice core from Greenland $\left(316^{\circ} \mathrm{E}, 71.4^{\circ} \mathrm{N}\right)$. Figure 13a shows the annual concentration of BC from 1850 until 2000 at the location of the D4 ice core together with the decadal median of the $\mathrm{BC}$ derived from the ice core (McConnell et al., 2007). The model results capture very well the results from McConnell et al. (2007). To see the possible role of inter annual variability due to meteorological factors and biomass burning emissions, the modelled annual concentrations of $\mathrm{BC}$ in the snow at the location of the D4 ice core for the years 2001-2008 are shown in Fig. 13b. There is a year to year variability in the BC concentration, with year 2006 giving the maximum $\mathrm{BC}$ concentration in the snow. Uncertainty bars based on the 2001-2008 variability are added to Fig. 13a, however there might have been long term changes in the circulations (e.g. connected to the Atlantic Multidecadal Oscillation) that could systematically affect the modelled concentrations.

In Table 2, the modelled burden of BC in snow north of $65^{\circ} \mathrm{N}$ is listed. As for burden of $\mathrm{BC}$ in the air, the modelled burden of $\mathrm{BC}$ in snow north of $65^{\circ} \mathrm{N}$ reached its maximum in the 1960s, about 4-5 decades later than the observations from ice core measurement from Greenland. This clearly shows that the $\mathrm{BC}$ deposition in snow in the Arctic is dominated by source regions that continued to increase significantly longer than the North American sources.

\subsection{Regional contributions to $\mathrm{BC}$ in the Arctic}

As shown in the previous section, the modelled burden of BC in snow in the Arctic had a maximum in 1960 (Table 2), while the maximum of $\mathrm{BC}$ measured in a Greenland ice core occurred earlier. To investigate this further, separate simulations were done with emissions in one region at the time. The regions considered are China, Russia and the rest of the Former Soviet Union (Russia and FSU), North America, EU17 (15 European Union countries plus Norway and Switzerland), the rest of Europe, and South Asia. The contribution from source regions to accumulated BC in the snow at the location of the D4 ice core at Greenland for year 1930 and 2000 are shown in Fig. 14a, b. According to the model, North American sources were responsible for approximately $80 \%$ of the BC deposited in Greenland snow in 1930. In year 2000 the contribution of BC deposited in the snow has decreased to approximately $60 \%$ due to the decrease in North American emissions.

For BC in snow in the whole Arctic region, we look at the contribution from each region to the modelled burden of $\mathrm{BC}$ in snow north of $65^{\circ} \mathrm{N}$ at the end of April (Fig. 14c, d). In 1930 Western Europe (EU17) was the main contributor to $\mathrm{BC}$ in the snow north of $65^{\circ} \mathrm{N}(37 \%)$, followed by Russia and FSU (28\%). The North American region contributed only $18 \%$ of the $\mathrm{BC}$ in snow in the Arctic region, which is much lower than the contribution to $\mathrm{BC}$ in snow in Greenland $(80 \%)$ at the same time. In the year 2000, the contribution from EU17 has decreased to $24 \%$ due to emission reductions. Together, EU17, Russia, and the rest of the FSU contribute half of the $\mathrm{BC}$ in snow in the Arctic region.

Shifting the focus to the atmosphere, the contribution to annual global mean BC in the atmosphere north of $65^{\circ} \mathrm{N}$ is shown in Fig. 14e for 1930 and Fig. 14f for year 2000. As for the burden of BC in the snow, EU17 was the main 


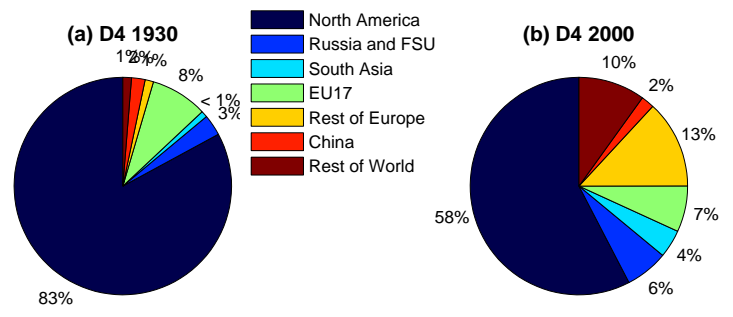

(c) Burden in snow N65 1930

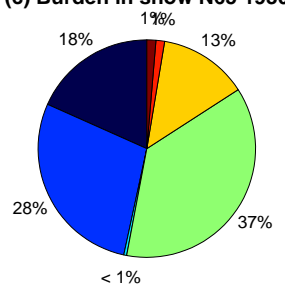

(d) Burden in snow N65 2000

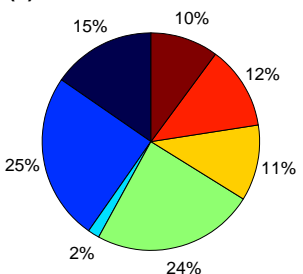

(e) Atmospheric burden N65 1930

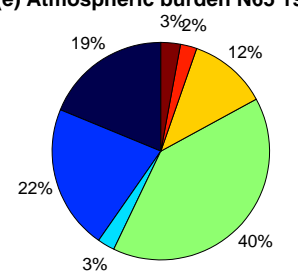

(f) Atmospheric burden N65 2000

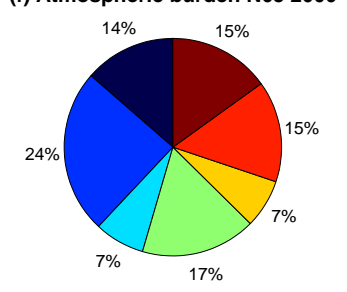

Fig. 14. Contribution of regions to $B C$ at the location of the $D 4$ ice core (a, b), BC in the snow north of 65 degrees (N65) end of April (c, d) and BC in the atmosphere north of 65 degrees $(\mathbf{e}, \mathbf{f})$. The left column shows results from the 1930 simulation and the right column for the year 2000 simulation.

contributor to total burden of BC in the atmosphere in the Arctic region in 1930 (40\%). Russia and FSU and North America followed by $22 \%$ and $19 \%$ of the total burden north of $65^{\circ} \mathrm{N}$. In year 2000 the contribution from EU17 is reduced to $17 \%$ and Russia and FSU is the main contributor with $24 \%$. China, a region with increasing emissions, contributes $15 \%$ of the atmospheric burden of BC north of $65^{\circ} \mathrm{N}$ in year 2000. Comparing the contribution from regions to the atmospheric burden and the burden in snow in the Arctic region, we can see that regions inside or close to the Arctic region (EU17, North America, Russia and FSU, Rest of Europe) have a larger or similar contribution to $\mathrm{BC}$ in snow than $\mathrm{BC}$ in the atmosphere. In contrast, regions further south, for example South Asia, contribute $7 \%$ to the atmospheric burden of BC in the Arctic but only $2 \%$ to the BC in the snow.

This contrast is related to the height distribution of the $\mathrm{BC}$ in the Arctic and the possibility for BC deposition in snow. $\mathrm{BC}$ emitted at low latitudes may be transported to the Arctic at higher altitudes where minimal precipitation occurs. In Fig. 15 the vertical distributions of the mean concentration of $\mathrm{BC}$ in the atmosphere north of $65^{\circ} \mathrm{N}$ from different emis-

sion source regions are shown for year 2000. In Fig. 15a the concentrations for the spring period (March-May) are plotted and in Fig. 15b for the summer months (June-August). For South Asia, which is located at low latitudes, the contribution to $\mathrm{BC}$ in the Arctic occurred at high altitudes. The $\mathrm{BC}$ emitted at lower latitudes will be transported pole-wards along isentropic surfaces, reaching the Arctic at high altitudes (Stohl, 2006). The BC will possibly be transported through the Arctic region without being deposited on the snow surfaces. China has its greatest contribution to the Arctic BC concentrations at high altitudes, but even also at the surface and in the middle troposphere China has a significant contribution to the Arctic BC concentrations during spring. For China, which has $30 \%$ of the global emissions, some of the emissions take place at higher latitudes, which will reach the cold Arctic at lower altitudes. In the summer months the concentration of $\mathrm{BC}$ from China in the lower and middle troposphere is reduced compared to the spring months. This may be due to the Polar front being at higher latitudes during summer, hindering emissions from further south from entering the Arctic region. Hirdman et al. (2010) found that in summer, the source region for the Arctic BC is close to or inside the Arctic region.

For the source regions at higher latitudes, Russia and FSU contribute the most to the $\mathrm{BC}$ concentration. In spring, this is the only region with a high contribution from biomass burning (Fig. 15a). Above $800 \mathrm{hPa}$, the contribution to $\mathrm{BC}$ concentration is higher for BB BC than FFBF BC. Concentrations from Russia and FSU peak at $500 \mathrm{hPa}$ due to the lifting of the $\mathrm{BC}$ emissions from biomass burning. In spring EU17 had a greater contribution than North America to the atmospheric BC concentration, whereas North America has a larger contribution to the BC concentration than EU17 in the summer except close to the surface, due to a large contribution from boreal forest fires in North America. For EU17 the contribution to the $\mathrm{BC}$ concentrations is mainly from FFBF $\mathrm{BC}$. At the surface the concentrations are slightly reduced from spring to summer, while substantially reduced in the middle troposphere. However in the upper troposphere an increase in the concentrations are modelled. This may be due to reduced low altitude transport of BC from Europe to the Arctic in the summer compared to spring, and more convective mixing of $\mathrm{BC}$ during summer giving a more homogeneous concentration through the troposphere.

\subsection{Radiative forcing}

The direct radiative forcing history for FFBF BC is calculated based on the concentration changes modelled by the Oslo CTM2. Figure 16a shows the calculated burden and radiative forcing history from 1850 until year 2000 relative to 1750 conditions. The global mean burden and RF increased mainly in two periods, the period prior to 1920 and after 1970. The first period is related to the industrialization in North America and Europe and the last one to increased 

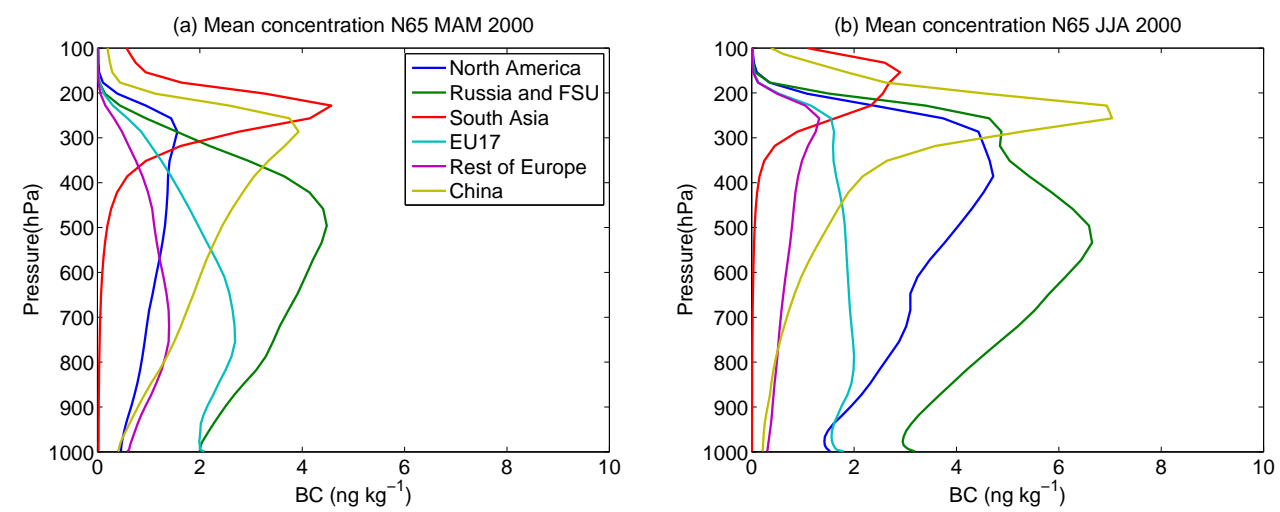

Fig. 15. Regional contribution to the mean BC concentration north of 65 degrees (N65) for March, April and May (a) and June, July and August (b).
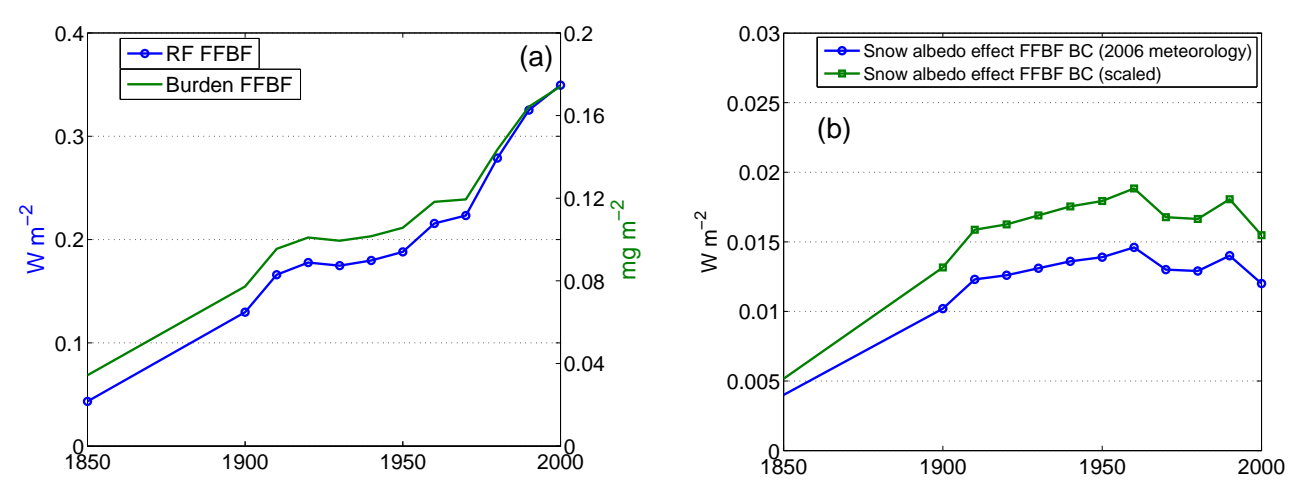

Fig. 16. Global mean burden and global mean radiative forcing for the direct aerosol effect of BC from fossil fuel and biofuel (a) and global mean radiative forcing for FFBF BC snow albedo effect (b). In (b) both results using 2006 meteorology and scaled results taking into account meteorological variability are shown.

emissions in the developing world. Figure $17 \mathrm{a}-\mathrm{c}$ shows the RF of the direct aerosol effect of FFBF BC for 1900, 1950, and 2000 relative to 1750 . The pattern of the RF is rather similar in 1900 and 1950, but with a stronger RF in the central northern Europe in 1950 compared to 1900 and relative to other source regions. The geographical pattern of RF in 2000 is quite different from 1900 and 1950, with a strong domination of the RF over Asia. Over Europe and northern America the BC RF has been reduced between 1950 and 2000 but over China and India the BC RF has increased by $5-10$ folds.

The calculated direct aerosol effect in year 2000 for FFBF $\mathrm{BC}$ is $0.35 \mathrm{~W} \mathrm{~m}^{-2}$, which is in the upper range of the direct aerosol effect of BC fossil fuel RF given in IPCC AR4 0.2 $[ \pm 0.15] \mathrm{W} \mathrm{m}^{-2}$ (Forster et al., 2007). The estimate is within $5 \%$ of the previous estimate of the direct aerosol effect of BC from Oslo CTM2 (Myhre et al., 2009). The IPCC estimate for the direct aerosol effect of FFBF BC included some models that treated $\mathrm{BC}$ as purely externally mixed, which is known to underestimate the direct RF (e.g. Jacobson, 2001; Chung and Seinfeld, 2002; Liao and Seinfeld, 2005; Bond and Bergstrom, 2006). The increase in RF in this study compared to the OsloCTM2 estimate in the AeroCom study (Schulz et al., 2006) is partly due to assumption of internal mixing for the hydrophilic aerosols, but also due to an increase in burden. Allowing internal mixing of BC increases the RF by approximately $25 \%$ compared to assumptions of purely external mixing in the mixing assumptions used in this study.

The time evolution of the RF of FFBF BC impact on snow and ice is shown in Fig. 16b. The time evolution shown in this figure differs substantially from the direct aerosol effect of BC with only small increase in the RF since 1910. The direct aerosol effect of FFBF BC is on the other hand doubled since 1910. The RF of BC impact on snow and ice maximizes in 1960, but remains within $20 \%$ of the RF in 1910. The geographical distribution of the RF of BC impact on snow and ice is shown in Fig. 18 for 1950 and 2000. In 1950 maximum values are found in the European and Russian sector of the Arctic Ocean and a secondary maximum is simulated over Europe. In 2000 the RF in the Arctic is reduced and the maximum over Europe is substantially 

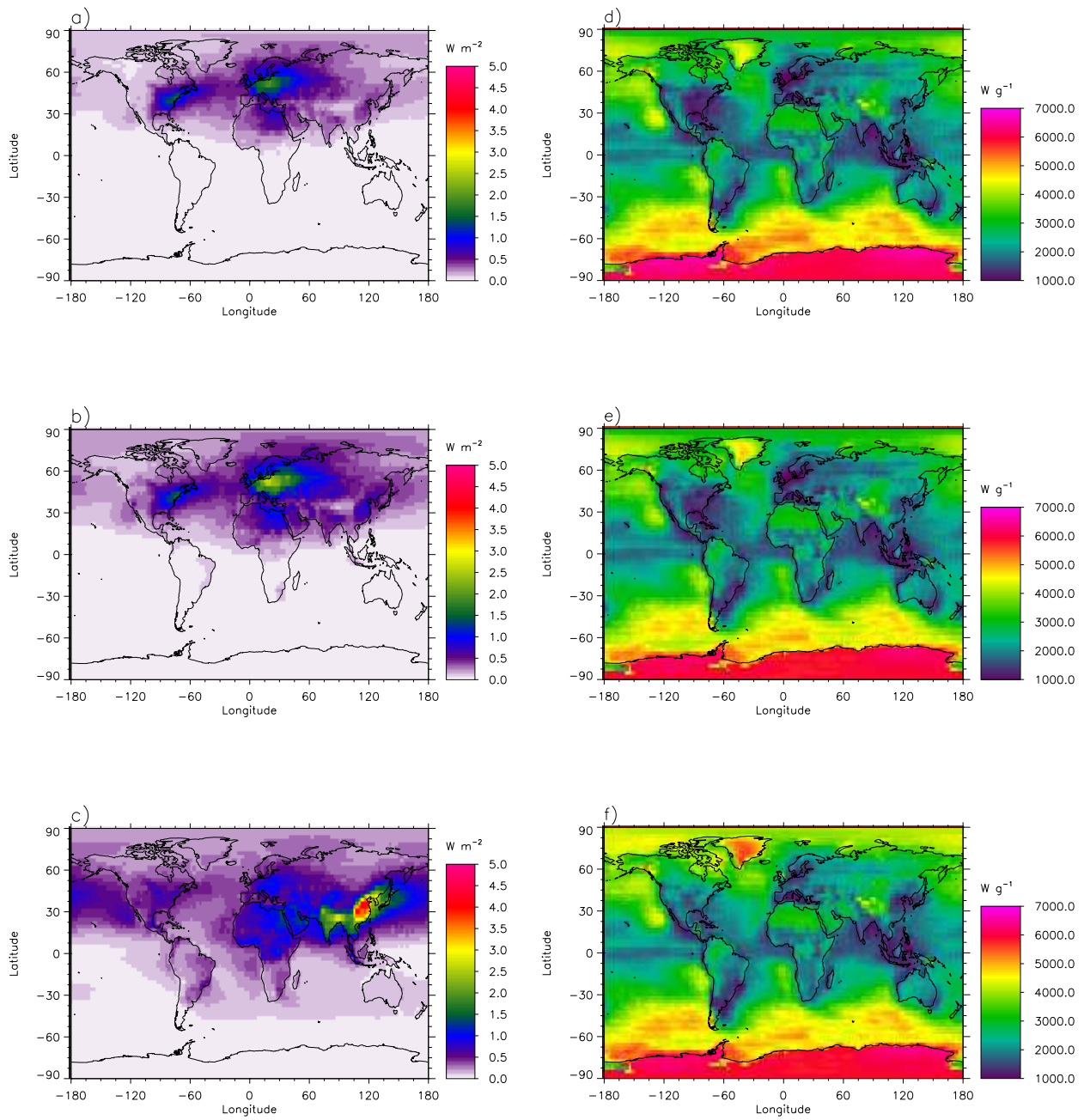

Fig. 17. RF of the direct aerosol effect of FFBF BC for 1900 (a), 1950 (b) and 2000 (c) relative to 1750. Normalized RF (RF divided by burden) of FFBF BC for 1900 (d), 1950 (e) and 2000 (f) relative to 1750.

reduced. Maximum values for year 2000 are found in the Himalayan region and the Tibetan plateau. The global and annual mean numbers are quite weak and only slightly higher than $0.01 \mathrm{~W} \mathrm{~m}^{-2}$ and thus even weaker than recent published estimates of FFBF BC RF from Flanner et al. (2007) and Rypdal et al. (2009) of 0.04 and $0.03 \mathrm{~W} \mathrm{~m}^{-2}$.

Koch et al. (2009a) calculated a RF for the 20th century of $0.01 \mathrm{~W} \mathrm{~m}^{-2}$. An earlier study by Jacobson (2004) calculated snow albedo reduction due to FFBF BC, giving a RF of $0.06 \mathrm{~W} \mathrm{~m}^{-2}$ (Flanner et al., 2007). For the calculations of the snow albedo effect there are differences among the studies related to snow aging, the resolution of the snow layers and assumption for melt water scavenging of $\mathrm{BC}$ in the snow in addition to the amount of BC deposited to the snow. Flanner et al. (2007) use the SNICAR model (Flanner and Zender, 2005) which couple snow aging and aerosol heating. Koch et al. (2009a) treat snow aging as a function of surface air temperature and snow age. Jacobson (2004) adopt a grain size of $150 \mu \mathrm{m}$, less than our assumption of $500 \mu \mathrm{m}$. The uncertainty in the RF related to the effective snow grain size adopted in our model is estimated to be $25 \%$ (Rypdal et al., 2009). Compared to Jacobson (2004), we keep track of the concentration of $\mathrm{BC}$ in the snow for the whole snow season using 10 snow layers. Koch et al. (2009a) use 1 to 3 snow layers, while Flanner et al. (2007) use several layers with the uppermost of $2 \mathrm{~cm}$ snow. We set the uppermost layer to $1 \mathrm{~mm}$ water equivalent (corresponding to about $0.3-1 \mathrm{~cm}$ of snow). In our study we assume the BC to remain in the surface layer during melting, while the others studies include melt water scavenging.

The calculated RF BC albedo effect is sensitive to the snow cover used in the simulations, since the interannual variation in the BC RF of snow and ice is found to be quite large. Simulations for the years 2001 to 2008 have been performed and the range is almost a factor of two with maximum in 2002 of $0.032 \mathrm{~W} \mathrm{~m}^{-2}$ to minimum in 2007 of 

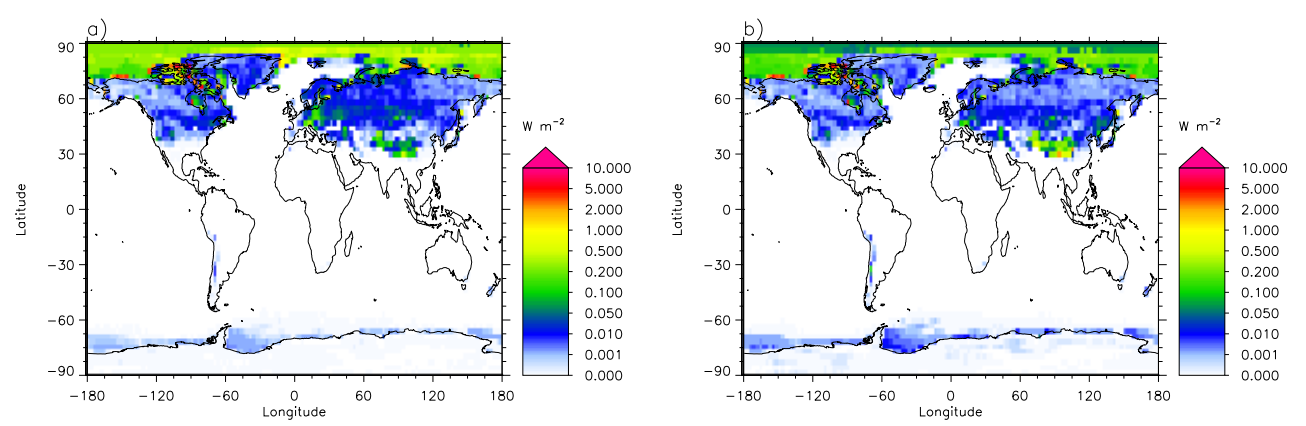

Fig. 18. RF of the snow albedo effect of FFBF BC for 1950 (a) and 2000 (b) relative to 1750.

$0.017 \mathrm{~W} \mathrm{~m}^{-2}$. Note that the simulations from 2001 to 2008 are performed with slightly different emissions than for the year 2000 and with reference no BC in snow instead of 1750 conditions in the RF calculations. The simulations for the period 1750 to 2000 are performed with meteorological data from 2006, a year with only slightly higher RF than in the minimum year 2007. Therefore our best estimate of the RF forcing series should be adjusted for the variability in the meteorological conditions. In Fig. 16b the scaled RF time series is added, with a $\mathrm{RF}$ for 2000 of $0.016 \mathrm{~W} \mathrm{~m}^{-2}$. It should be noted that any changes in the historical snow cover, e.g. larger snow cover and a longer snow season historically compared to 2005-2006, may have reduced the RF of BC in snow during more recent years.

\section{Discussion}

To be able to use a model to understand the historical trends in the concentration of $\mathrm{BC}$ and $\mathrm{RF}$, it is important that the model gives a reasonable description of the current distribution $\mathrm{BC}$ in the atmosphere and in snow. Comparison of the model results with observations is however challenging due to the large uncertainties in the measurements and the relatively coarse grid of the model. Observations are given either as $\mathrm{EC}$ or EBC, based on the measurement technique used (thermo-optical or optical method). Equivalent black carbon is based on measurement of attenuation of light by particles accumulated on a filter through application of a mass absorption cross section (MAC) to get EBC concentrations. The reported value for the MAC in the literature are in the range 1-30 $\mathrm{m}^{2} \mathrm{~g}^{-1}$ (Andreae and Gelencsér, 2006) depending on both aerosol properties and measurement uncertainties. We have used a standard value $9.7 \mathrm{~m}^{2} \mathrm{~g}^{-1}$ (Bond and Bergstrom, 2006) for the US sites in Fig. 3. The use of aerosol light absorption may over predict the observed $\mathrm{BC}$ due to attenuation of light by other aerosols like mineral dust and organics. However, there are also methodological issues with the thermo-optical method related to the ability to discriminate between EC and other forms of carbon on the filters. According to Vignati et al. (2010) the optical methods tend to give 1 to 3 times higher concentrations than the thermooptical methods. The relatively coarse grid of the model may complicate the comparison with observations, since emission cover the whole grid box and may affect measurement sites normally unaffected by the emissions. Taking into account the uncertainties above, there is relatively good consistency between model results and observations, however the observations are sparse and lacking for large part of the world. The introduction of aging times depending on season and latitude gives a better seasonal cycle of the BC concentration at Arctic stations. However, there still appears to be an underestimation of the concentration of $\mathrm{BC}$ during spring, keeping in mind that most of the Arctic measurements are done with the optical method. For the global mean RF of the direct aerosol effect the possible underestimation of $\mathrm{BC}$ concentrations in the Arctic during spring will not change the results significantly.

Comparing the modelled and observed vertical profiles of $\mathrm{BC}$, the model tends to overestimate the $\mathrm{BC}$ in the upper troposphere. This is seen at lower latitudes above $600 \mathrm{hPa}$ in Fig. 6a and at higher latitudes above $300 \mathrm{hPa}$ in Fig. $6 \mathrm{~b}$. $\mathrm{BC}$ may be transported too effectively to high altitudes in the model, or the scavenging might be too slow for the $\mathrm{BC}$ that has reached those high altitudes. In the remote Pacific (Fig. 7), the model overestimates at all altitudes. Schwarz et al. (2010) found that the AeroCom models also tend to over predict the observed $\mathrm{BC}$ from the flight campaign in the remote Pacific especially at high altitudes, and attributed this to insufficient wet removal of BC. Also Vignati et al. (2010) pointed out wet removal as a main uncertainty of modelling $\mathrm{BC}$ concentration. The estimate of radiative forcing is particularly sensitive to an overestimation of $\mathrm{BC}$ at high altitudes since the $\mathrm{BC}$ can then be located above the clouds. Zarzycki and Bond (2010) estimate that the overestimation of RF could be up to $40 \%$.

Uncertainties in the vertical distribution of $\mathrm{BC}$ influence the calculated contribution of $\mathrm{BC}$ to the Arctic region from South Asia and China. As seen in Fig. 15, these two regions mainly contribute to $\mathrm{BC}$ at high altitudes in the Arctic, while at lower altitudes they are of minor importance. This is consistent with the findings from Stohl et al. (2006), 
Shindell et al. (2008) and Hirdman et al. (2010), while Koch and Hansen (2005) stated that Asia had equal contribution to the Arctic as Europe. If $\mathrm{BC}$ concentrations at high altitudes are overestimated due to insufficient wet removal, the contribution of $\mathrm{BC}$ to the Arctic from regions at lower latitudes is overestimated.

There are large spreads in the observed levels of BC in snow, even for measurements taken in the same local area at the same time, due to natural variability caused by topography effects and snow drift (Forsström et al., 2009). In addition there are uncertainties related to the sampling procedure (e.g. BC sticking to containers used for snow collection) in the measurement techniques (see above). Comparing the model results with the observations, we rather underestimate than overestimate the concentrations of BC in snow. Especially in northern Russia, there is a tendency for the modelled concentrations of $\mathrm{BC}$ in snow in spring to be lower than the observed values indicating missing emission sources.

The global mean radiative forcing has increased over time (Fig. 16a). As seen in Fig. 16a, the RF has increased faster then the global mean burden. Investigating this further, the time history of the ratios between annual global-mean burden and emissions, and of radiative forcing and column burden, for FFBF BC are shown in Fig. 19. The burden and annual emissions of FFBF BC vary nearly linearly from 1850 1950 , but their ratio (the lifetime) increased by $12 \%$ during the second half of the 20th century. This is related to an increase in the lifetime of FFBF BC (Table 2), due to a south- and eastward shift in the emissions. The ratio between $\mathrm{RF}$ and column burden increased by $59 \%$ during the whole simulation period (Fig. 19). The increase is seen for the periods 1850-1910 (38\%) and 1950-2000 (13\%), with little change between 1910 and 1950 . The change in forcing per unit of emissions was $80 \%$ for the whole simulation period and $26 \%$ since 1950 . The cause of the increase in the global RF/burden can be seen from Fig. 17d-f, which shows the geographical distribution of normalized RF (RF divided by column burden). The normalized RF is slightly higher over China and India than over Europe and northern America, and with a shift in the emissions this impacts the global mean RF. At lower latitudes there is more sunlight and more transport of $\mathrm{BC}$ to higher altitudes which contributes to more effective forcing. Haywood and Ramaswamy (1998) showed a pattern of the normalized RF of BC with larger values at higher latitudes and lower values in coastal areas. In our results, the larger fraction of hydrophobic BC, and thus lower absorption coefficient, close to the source regions reduces the normalized RF in these locations. Also seen in Fig. 17 is an increase in the normalized RF in the Arctic from 1950 to 2000. This is due to the influence of increased emissions at lower latitudes reaching the Arctic at high altitude above clouds, giving increased normalised RF. The normalized RF with respect to AOT shows similar development as the normalized RF with respect to burden both close to source regions and in the Arctic. Worth keeping in mind is that increased RF in the Arctic

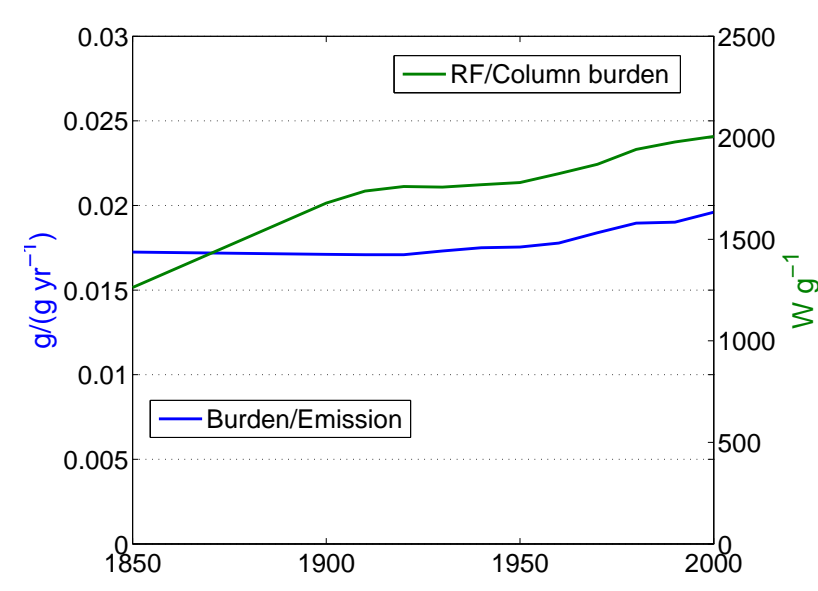

Fig. 19. Time history of the ratios of global-mean annual emissions and total burden, and of column burden and radiative forcing, for FFBF BC.

region may not necessarily give increased temperature in the Arctic. A GCM study by Shindell and Faluvegi (2009) indicates that regional RF in the Arctic due to absorbing aerosols in the atmosphere does not give increased surface temperature in the Arctic since it leads to a reduced temperature gradient between the Arctic and mid-latitudes which caused a reduction in the northward heat transport by transient eddies.

For the historical simulations, the model confirms the increase in BC concentrations over the north east US up until 1920 that was inferred from measurements of BC in sediment cores (Husain et al., 2008). In the model, the increase is less steep and also the concentrations decline until 1960, while the measurements indicate quite stable BC concentrations until 1960 followed by a rapid decline. An even better agreement is obtained for BC from the D4 ice core from Greenland, although here as well the 1850 concentrations are somewhat overestimated in the model. In this work, we use the same meteorology for the historical simulations, due to lack of historical meteorological data and due to the concept of radiative forcing where meteorological conditions should be kept fixed. However, during the last $100 \mathrm{yr}$, it is likely that there have been changes in the circulation patterns related to the Atlantic multidecadal variability (Bengtsson et al., 2004). In the 1930s there was a warm period with a positive NAO-index, followed by a cold period with a negative NAO-index around 1950, and then the rapid warming at the end of the 20th century. A positive phase of the NAO-index tend to correspond with increase of the pollutant transport to the Arctic (Eckhardt et al., 2003), which must be taken into account when comparing the historical results with observations. Taking the variability found in the 2000-2008 simulations as a measure of this variability, we find that circulation changes can only explain a small part of the observed variability since 1850 . Changes in the circulation patterns influence the distribution of $\mathrm{BC}$ in the atmosphere, and 
precipitation changes will influence the $\mathrm{BC}$ concentration in snow. This must also be taken into account when interpreting the regional contributions of $\mathrm{BC}$ to the Arctic. Using 20002001 meteorology for the regional contribution to $\mathrm{BC}$ in the Arctic instead of the 2005-2006 meteorology, North America's contribution to Greenland (corresponding to data from the $\mathrm{D} 4$ ice core) is reduced from 83 to $63 \%$ in 1930 and from 58 to $42 \%$ in year 2000 . For burden in snow north of $65^{\circ} \mathrm{N}$, the contribution is reduced from $18 \%$ to $11 \%$ in year 1930 and from $15 \%$ to $11 \%$ in year 2000 . For the atmospheric burden north of $65^{\circ} \mathrm{N}$, the contributions from all regions are similar using either 2000-2001 meteorology or 2005-2006 meteorology. Although the contribution from North America to Greenland is smaller using another meteorological year, the same conclusion can be made that North America contributed relatively more to $\mathrm{BC}$ in the snow in Greenland than to the whole Arctic region, which is consistent with other studies (e.g. Shindell et al., 2008).

For the modelling of historical concentrations of BC, the use of the same set of aging times for all years may not be realistic, due to changes in the $\mathrm{SO}_{2}$ emissions over the period (Smith et al., 2011). McConnell and Edwards (2008) showed a rapid increase in the non sea salt sulphur concentration at the ACT2 ice core at Greenland after 1950. This might have influenced the aging of $\mathrm{BC}$ aerosols, since the estimated aging time is dependent on the sulphur concentration. A higher sulphate concentration and thus a shorter aging time would reduce BC transport over long distances. Stier et al. (2006) found that the atmospheric lifetime of $\mathrm{BC}$ was reduced from 4.3 days in the pre-industrial atmosphere to 3.8 days for year 2000 conditions.

There are large uncertainties in the emissions estimates, in particular for the historic emissions and for emissions from the use of biofuel and open biomass burning. Bond et al. (2007) assumed an uncertainty of a factor of 2 for the total global inventory of current emissions. For the historical emissions there are great uncertainties related to activity data, technology split and emission factors, and the rate of change in these factors. The uncertainties in the rate of change in the emissions are not estimated in Bond et al. (2007). In addition there are uncertainties in the spatial distribution of the emissions that are not quantified. There are even larger uncertainties in the biomass burning emissions, especially in the pre-satellite era (Lamarque et al., 2010).

Chemical analysis of the snow (Hegg et al., 2009, 2010) showed that a large fraction of BC collected in springtime snow had a biomass source. Also in the atmosphere, fires in Russia are an important contributor to springtime BC concentrations in the Arctic (Warneke et al., 2010). In the model, most of the $\mathrm{BC}$ in the Arctic is related to fossil fuel and biofuel combustion. The fraction of annual mean $\mathrm{BB} B \mathrm{BC}$ to total $\mathrm{BC}$ burden north of $65^{\circ} \mathrm{N}$ ranges from 15 to $36 \%$ in the 2001-2008 simulation. In the snow the amount of BB $\mathrm{BC}$ at the end of April is much lower than the FFBF BC (6 to $11 \%$ of total $\mathrm{BC}$ in snow). This is not in agreement with the results from Hegg et al. (2009, 2010), although biofuel will be accounted as a biomass source in their analysis. This indicates that there may be missing sources of biomass burning in our model. It is also worth noting the very small contribution of $\mathrm{BB} \mathrm{BC}$ in the Arctic region in the historical period 1930 to 1990 , with $\mathrm{BB} \mathrm{BC}$ accounting for 8 to $16 \%$ of the total atmospheric $\mathrm{BC}$ north of $65^{\circ} \mathrm{N}$. This is due to low historical emission estimates from boreal fires. In the period 2001-2008 the fraction of biomass burning emissions north of $40^{\circ} \mathrm{N}$ to global emissions ranged from 13 to $32 \%$. In the historical simulations however, this fraction was less than $13 \%$ for all the years between 1900 and 1990 .

\section{Conclusions}

The transport of $\mathrm{BC}$ in the atmosphere and the deposition of $\mathrm{BC}$ on snow surfaces since pre-industrial times have been modelled with the Oslo CTM2 model. From these model results radiative forcing histories for both the direct aerosol effect and snow albedo effect of BC from fossil fuel and biofuel sources are calculated. The modelled global mean radiative forcing of the direct aerosol effect of FFBF BC is $0.35 \mathrm{~W} \mathrm{~m}^{-2}$ and the snow albedo effect $0.016 \mathrm{~W} \mathrm{~m}^{-2}$ in year 2000, relative to pre-industrial times. A formal error propagation analysis is difficult to perform. Related to the ranges given in the IPCC AR4 (Forster et al., 2007), our results for the direct aerosol effect is in the higher range [0.05$\left.0.35 \mathrm{~W} \mathrm{~m}^{-2}\right]$ and for the snow albedo effect in the lower range $\left[0-0.2 \mathrm{~W} \mathrm{~m}^{-2}\right]$ given by the IPCC.

The global mean burden and direct aerosol effect of FFBF BC increased in two periods, before 1920 related to emissions in North America and Europe and after 1970 related to increasing emissions in East Asia. Due to the shift in spatial distribution of the emissions, the geographic distribution of $\mathrm{RF}$ and burden of FFBF BC have shifted southwards, leading to an increase in the normalized radiative forcing of $\mathrm{BC}$.

We find that the time evolution of the snow albedo effect is almost flat, with no significant increase in this forcing since early 20th century. Modelled BC burden in snow and ice and $\mathrm{BC}$ burden in the atmosphere north of $65^{\circ} \mathrm{N}$ reached its maximum in 1960 , with a slight reduction thereafter. This indicates that the trend in the snow albedo effect has not been an important cause for the recent rapid warming in the Arctic.

For modelling of $\mathrm{BC}$ in the atmosphere, there are uncertainties related to the emission estimates used, to the aging of the aerosols, to the transport of aerosols and to removal processes of $\mathrm{BC}$ from the atmosphere. Also comparing with observations is challenging due to high uncertainty in the observations and even in the definition of what BC exactly is. Comparing the model results with observations, we tend to overestimate $\mathrm{BC}$ at high altitudes (above $500 \mathrm{hPa}$ in tropics and mid-latitudes, and $300 \mathrm{hPa}$ in the Arctic), indicating that wet deposition processes in the models may need improvements. For the historical period, changes in the circulation 
patterns and changes in concentration of species that affect the aging of $\mathrm{BC}$ will affect the comparison of model results with $\mathrm{BC}$ concentrations derived from ice and sediment cores. The observed BC-maximum in snow on Greenland early in the 20th century is reproduced by the model. However, we find a slower reduction thereafter compared to the observations. In future work historical simulations with aging times coupled to the sulphur concentrations would be useful, due to the rapid increase in sulphur emissions from the middle of 20th century.

There are indications that there is more $\mathrm{BC}$ from biomass sources in snow samples than what we find in our model results. We find a very small fraction of $\mathrm{BB} B \mathrm{BC}$ in the atmosphere and in the snow north of $65^{\circ} \mathrm{N}$, especially for the historical time periods. The fact that the model seems to underestimate $B C$ in snow in Northern Russia, shows too little influence of BB BC in Arctic snow, and underestimates BC in the lower and mid-troposphere at high latitudes indicates that there are missing emissions of $\mathrm{BC}$ from biomass at midto high northern latitudes in particular during spring. Focus on biomass burning emission inventories and more observations, and source attribution, of BC in air and snow in Northern Eurasia would be useful for model improvements.

The direct aerosol effect of FFBF BC in year 2000 of $0.35 \mathrm{~W} \mathrm{~m}^{-2}$ relative to pre-industrial times corresponds to $21 \%$ of the RF of $\mathrm{CO}_{2}$ (Forster et al., 2007). Early in the 20th century (1900-1920), the forcing from FFBF BC was up to almost $40 \%$ of the $\mathrm{RF}$ of $\mathrm{CO}_{2}$. The very different time evolution of the forcing from $\mathrm{BC}$ compared to long lived greenhouse gases and ozone might be important for understanding the change in the global mean temperature over the last $150 \mathrm{yr}$. The maximum rate of change of the forcing from BC occurred in two periods, prior to 1920 and after 1970, which coincides with the periods where global mean temperature increased the most (Trenberth et al., 2007), and should be investigated further in attribution studies.

\section{Appendix A}

\section{Model description: atmospheric removal}

In the carbonaceous scheme used in the Oslo CTM2, $\mathrm{BC}$ aerosols are divided into hydrophilic and hydrophobic aerosols. At the time of emission, $80 \%$ of the $\mathrm{BC}$ is assumed to be hydrophobic and the remaining fraction hydrophilic. The hydrophobic aerosols age (oxidize or get coated by hydrophilic compounds) and become hydrophilic. The aerosols are removed from the atmosphere by dry or wet deposition. Only hydrophilic aerosols are scavenged by wet deposition. The aerosols are removed according to the fraction of water content of the cloud removed by precipitation. For large scale precipitation, $100 \%$ scavenging is assumed in water clouds, and $12 \%$ for ice clouds. For convective precipitation, $100 \%$ scavenging is assumed. Below-cloud scavenging is not accounted for in the model. A dry deposition velocity of $0.025 \mathrm{~cm} \mathrm{~s}^{-1}$ is used for both hydrophilic and hydrophobic aerosols over land, while over ocean hydrophilic aerosols have a deposition velocity of $0.2 \mathrm{~cm} \mathrm{~s}^{-1}$ and hydrophobic aerosols a deposition velocity of $0.025 \mathrm{~cm} \mathrm{~s}^{-1}$.

\section{Appendix B}

\section{Model description: snow}

The Oslo CTM2 model is expanded with a routine that generates snow layers and $\mathrm{BC}$ contents in these layers.

Snow data from the ECMWF are used to build up snow layers in each grid box. Since the radiative effect of BC is largest for $\mathrm{BC}$ close to the snow surface, we limit the total number of snow layers to 10. Snow depth from the ECMWF data are used to initialize the snow depth, snow fall data are used to build up the snow layers and snow evaporation and snow melt data are used to reduce the snow layers. The amount of $\mathrm{BC}$ that is removed from the atmosphere due to dry or wet deposition is stored and the concentration of $\mathrm{BC}$ in each snow layer can be calculated.

The BC content at the snow surface is very important for the reflectivity of the snow. Since dry deposition of BC, although small compared to the wet deposition, may be of particular importance, the uppermost snow layer is set to be not thicker than $1 \mathrm{~mm}$ of water equivalent. If a snowfall is greater than $1 \mathrm{~mm}$ of water equivalent, the upper layer is split in two when the snowfall ends, with the thickness of the uppermost layer $1 \mathrm{~mm}$ of water equivalent.

A maximum of 10 snow layers can be build. The snow data from ECMWF are updated every $3 \mathrm{~h}$, and to avoid generating too many layers, a new snow layer will not be generated if it has been snowing in the last $24 \mathrm{~h}$. The snowfall will be added together with the uppermost thin layer and the layer beneath, and a new thin surface layer will be made. When the maximum number of snow layers is reached, the two bottom layers are merged if a new snow layer is generated.

In each time step $\mathrm{BC}$ is dry deposited to the surface layer. For wet deposition of $\mathrm{BC}$, if a snowfall is greater than $1 \mathrm{~mm}$ of water equivalent, the $\mathrm{BC}$ content is split between the surface layer and the thicker layer underneath, giving an equal concentration of $\mathrm{BC}$ in both layers. When the two bottom layers are merged, the $\mathrm{BC}$ contents are merged as well.

The snowmelt and evaporation data from ECMWF are used to reduce the thickness of the snow layers and to remove them. During melting and evaporation of snow, the BC from the removed snow is assumed to remain at the surface of the snowpack. A new surface layer is generated containing the $\mathrm{BC}$ in the old surface layer and the fraction of $\mathrm{BC}$ in the sub-surface layer that has melted/evaporated. Thus, the $\mathrm{BC}$ content in the snow column is conserved until the whole snow column has melted. Then all the BC is removed. 
After adding new snow layers and melting existing snow layers, the total snow depth in the CTM2 routine may not exactly match the snow depth value from the ECMWF data. This discrepancy is resolved by keeping the upper thin layer as it is, and scaling the water equivalents of all the other snow layers to match the total snow depth from the ECMWF data. The mass of $\mathrm{BC}$ in the snow is not changed. When the snow depth in the ECMWF data is very large (e.g. on glaciers), the snow depth data in ECMWF is kept constant. If the snow depth is larger than $1 \mathrm{~m}$ of water equivalent, we do not scale our snow layer with the total snow depth from the ECMWF data. If new snow layers are generated, and there is no snow depth in the ECMWF data, the snow layers and BC content are removed. If new snow layers are not generated, and there are snow depths in the ECMWF data, new clean snow layers are initialized.

The ECMWF snow depth, snow melt and snow evaporation data do not exist for grid boxes with sea ice. During winter (until mid May), snow layers are generated from the snow fall data if the sea ice extent is greater than $30 \%$, assuming no removal. The removal of snow during the melting season is treated quite simply. In the Northern Hemisphere, the snow is assumed to melt at a constant rate from mid May to late June. On 21 June we assume that all the snow has melted. If there is a new snowfall in this period the rate of melting is changed, so that all the snow will still be gone by 21 June. Until 8 August new snow layers on the sea ice are not allowed to form. The BC content kept at the surface of the sea ice, and the snow depth on a snow-free sea ice surface is set to $1 \mathrm{~mm}$ of water equivalent. In the SouthernHemisphere, snow layers on the sea ice undergo melting in the period between 15 October and 20 December, and new snow layers are not generated before 6 February.

If the sea ice extent is below $30 \%$, all the snow is melted immediately and all the $\mathrm{BC}$ is removed.

Acknowledgements. We thank the NOAA/ESRL/GMD aerosol group, Liaquat Husain, Joseph R. McConnell, J. P. Schwarz, Dorothy Koch, Norwegian Institute for Air Research, Leibniz Institute for Tropospheric Research and Institute of Environmental Assessment and Water Research for providing data. We are grateful to Sanja Forsström and Sverdrup Station personnel at Ny-Ålesund (Norwegian Polar Institute) for help with sampling and sample processing. Thanks to Abisko research station and Finnish Meteorological Institute for help in collecting snow samples in Abisko and Pallas. Also thanks to the Swedish Environmental Protection Agency for supporting aerosol measurements at the Zeppelin station. This research was supported by the Norwegian Research Council under the projects "Measurements of Black Carbon Aerosols in Arctic Snow - Interpretation of Effect on Snow Reflectance", "Climate Effects of Reducing Black Carbon Emissions", and "Constraining total feedback of the climate system by observations and models" and the NOAA Atmospheric Composition and Climate Program.

Edited by: E. Vignati

\section{References}

Aamaas, B., Bøggild, C. E., Stordal, F., Berntsen, T., Holmén, K. I. M., and Ström, J.: Elemental carbon deposition to Svalbard snow from Norwegian settlements and long-range transport, Tellus B, 63, 340-351, doi:10.1111/j.1600-0889.2011.00531.x, 2011.

Andreae, M. O. and Gelencsér, A.: Black carbon or brown carbon? The nature of light-absorbing carbonaceous aerosols, Atmos. Chem. Phys., 6, 3131-3148, doi:10.5194/acp-6-3131-2006, 2006.

Andrews, E., Sheridan, P. J., Ogren, J. A., and Ferrare, R.: In situ aerosol profiles over the Southern Great Plains cloud and radiation test bed site: 1. Aerosol optical properties, J. Geophys. Res., 109, D06208, doi:10.1029/2003jd004025, 2004.

Andrews, E., Sheridan, P. J., and Ogren, J. A.: Seasonal differences in the vertical profiles of aerosol optical properties over rural Oklahoma, Atmos. Chem. Phys. Discuss., 11, 11939-11957, doi:10.5194/acpd-11-11939-2011, 2011.

Bauer, S. E., Menon, S., Koch, D., Bond, T. C., and Tsigaridis, K.: A global modeling study on carbonaceous aerosol microphysical characteristics and radiative effects, Atmos. Chem. Phys., 10, 7439-7456, doi:10.5194/acp-10-7439-2010, 2010.

Bengtsson, L., Semenov, V. A., and Johannessen, O. M.: The early twentieth-century warming in the Arctic - A possible mechanism, J. Clim., 17, 4045-4057, 2004.

Berglen, T. F., Berntsen, T. K., Isaksen, I. S. A., and Sundet, J. K.: A global model of the coupled sulfur/oxidant chemistry in the troposphere: The sulfur cycle, J. Geophys. Res., 109, D19310, doi:10.1029/2003jd003948, 2004.

Berntsen, T., Fuglestvedt, J., Myhre, G., Stordal, F., and Berglen, T. F.: Abatement of greenhouse gases: Does location matter?, Clim. Change, 74, 377-411, 2006.

Bond, T. C. and Bergstrom, R. W.: Light absorption by carbonaceous particles: An investigative review, Aerosol Sci. Tech., 40, 27-67, doi:10.1080/02786820500421521, 2006.

Bond, T. C., Habib, G., and Bergstrom, R. W.: Limitations in the enhancement of visible light absorption due to mixing state, J. Geophys. Res., 111, D20211, doi:10.1029/2006jd007315, 2006.

Bond, T. C., Bhardwaj, E., Dong, R., Jogani, R., Jung, S. K., Roden, C., Streets, D. G., and Trautmann, N. M.: Historical emissions of black and organic carbon aerosol from energy-related combustion, 1850-2000, Global Biogeochem. Cy., 21, Gb2018, doi:10.1029/2006gb002840, 2007.

Brock, C. A., Cozic, J., Bahreini, R., Froyd, K. D., Middlebrook, A. M., McComiskey, A., Brioude, J., Cooper, O. R., Stohl, A., Aikin, K. C., de Gouw, J. A., Fahey, D. W., Ferrare, R. A., Gao, R.-S., Gore, W., Holloway, J. S., Hbler, G., Jefferson, A., Lack, D. A., Lance, S., Moore, R. H., Murphy, D. M., Nenes, A., Novelli, P. C., Nowak, J. B., Ogren, J. A., Peischl, J., Pierce, R. B., Pilewskie, P., Quinn, P. K., Ryerson, T. B., Schmidt, K. S., Schwarz, J. P., Sodemann, H., Spackman, J. R., Stark, H., Thomson, D. S., Thornberry, T., Veres, P., Watts, L. A., Warneke, C., and Wollny, A. G.: Characteristics, sources, and transport of aerosols measured in spring 2008 during the aerosol, radiation, and cloud processes affecting Arctic Climate (ARCPAC) Project, Atmos. Chem. Phys., 11, 2423-2453, doi:10.5194/acp-11-24232011, 2011.

Chen, W. T., Lee, Y. H., Adams, P. J., Nenes, A., and Seinfeld, J. H.: Will black carbon mitigation dampen aerosol indirect forcing?, Geophys. Res. Lett., 37, L09801, doi:10.1029/2010g1042886, 
2010.

Cheng, Y. F., Eichler, H., Wiedensohler, A., Heintzenberg, J., Zhang, Y. H., Hu, M., Herrmann, H., Zeng, L. M., Liu, S., Gnauk, T., Bruggemann, E., and He, L. Y.: Mixing state of elemental carbon and non-light-absorbing aerosol components derived from in situ particle optical properties at Xinken in Pearl River Delta of China, J. Geophys. Res., 111, D20204, doi:10.1029/2005jd006929, 2006.

Chung, C. E., Ramanathan, V., Kim, D., and Podgorny, I. A.: Global anthropogenic aerosol direct forcing derived from satellite and ground-based observations, J. Geophys. Res., 110, D24207, doi:10.1029/2005jd006356, 2005.

Chung, S. H. and Seinfeld, J. H.: Global distribution and climate forcing of carbonaceous aerosols, J. Geophys. Res., 107(D19), 4407, doi:10.1029/2001jd001397, 2002.

Clarke, A. D. and Noone, K. J.: Soot in the arctic snowpack - a cause for perturbations in radiative-transfer, Atmos. Environ., 19, 2045-2053, 1985.

Cooke, W. F., Liousse, C., Cachier, H., and Feichter, J.: Construction of a 1 degrees $\times 1$ degrees fossil fuel emission data set for carbonaceous aerosol and implementation and radiative impact in the ECHAM4 model, J. Geophys. Res., 104, 22137-22162, 1999.

Dentener, F., Kinne, S., Bond, T., Boucher, O., Cofala, J., Generoso, S., Ginoux, P., Gong, S., Hoelzemann, J. J., Ito, A., Marelli, L., Penner, J. E., Putaud, J.-P., Textor, C., Schulz, M., van der Werf, G. R., and Wilson, J.: Emissions of primary aerosol and precursor gases in the years 2000 and 1750 prescribed data-sets for AeroCom, Atmos. Chem. Phys., 6, 4321-4344, doi:10.5194/acp6-4321-2006, 2006.

Doherty, S. J., Warren, S. G., Grenfell, T. C., Clarke, A. D., and Brandt, R. E.: Light-absorbing impurities in Arctic snow, Atmos. Chem. Phys., 10, 11647-11680, doi:10.5194/acp-1011647-2010, 2010.

Eckhardt, S., Stohl, A., Beirle, S., Spichtinger, N., James, P., Forster, C., Junker, C., Wagner, T., Platt, U., and Jennings, S. G.: The North Atlantic Oscillation controls air pollution transport to the Arctic, Atmos. Chem. Phys., 3, 1769-1778, doi:10.5194/acp3-1769-2003, 2003.

Eleftheriadis, K., Vratolis, S., and Nyeki, S.: Aerosol black carbon in the European Arctic: Measurements at Zeppelin station, Ny-Alesund, Svalbard from 1998-2007, Geophys. Res. Lett., 36, L02809, doi:10.1029/2008gl035741, 2009.

EMEP: Status report 4/2010, Transboundary particulate matter in Europe, 2010.

Flanner, M. G. and Zender, C. S.: Snowpack radiative heating: Influence on Tibetan Plateau climate, Geophys. Res. Lett., 32, L06501, doi:10.1029/2004GL022076, 2005.

Flanner, M. G., Zender, C. S., Randerson, J. T., and Rasch, P. J.: Present-day climate forcing and response from black carbon in snow, J. Geophys. Res., 112, D11202, doi:10.1029/2006JD008003, 2007.

Flanner, M. G., Zender, C. S., Hess, P. G., Mahowald, N. M., Painter, T. H., Ramanathan, V., and Rasch, P. J.: Springtime warming and reduced snow cover from carbonaceous particles, Atmos. Chem. Phys., 9, 2481-2497, doi:10.5194/acp-9-24812009, 2009.

Forsström, S., Ström, J., Pedersen, C. A., Isaksson, E., and Gerland, S.: Elemental carbon distribution in Svalbard snow, J. Geophys.
Res., 114, D19112, doi:10.1029/2008jd011480, 2009.

Forster, P., Ramaswamy, V., Artaxo, P., Berntsen, T., Betts, R., Fahey, D. W., Haywood, J., Lean, J., Lowe, D. C., Myhre, G., Nganga, J., Prinn, R., Raga, G., Schulz, M., and Dorland, R. V.: Changes in Atmospheric Constituents and in Radiative Forcing, in: Climate Change 2007: The Physical Science Basis. Contribution of Working Group I to the Fourth Assessment Report of the Intergovernmental Panel on Climate Change, edited by: Solomon, S., Qin, D., Manning, M., Chen, Z., Marquis, M., Averyt, K. B., Tignor, M., and Miller, H. L., Cambridge Univ. Press, Cambridge and New York, 2007.

Grenfell, T. C., Light, B., and Sturm, M.: Spatial distribution and radiative effects of soot in the snow and sea ice during the SHEBA experiment, J. Geophys. Res., 107, 8032, doi:10.1029/2000jc000414, 2002.

Grenfell, T. C., Doherty, S. J., Clarke, A. D., and Warren, S. G.: Spectrophotometric determination of absorptive impurities in snow, Appl. Opt., in review, 2011.

Hansen, J. and Nazarenko, L.: Soot climate forcing via snow and ice albedos, P. Natl. Acad. Sci. USA, 101, 423-428, 2004.

Hara, K., Yamagata, S., Yamanouchi, T., Sato, K., Herber, A., Iwasaka, Y., Nagatani, M., and Nakata, H.: Mixing states of individual aerosol particles in spring Arctic troposphere during ASTAR 2000 campaign, J. Geophys. Res., 108, 4209, doi:10.1029/2002jd002513, 2003.

Haywood, J. M. and Shine, K. P.: The effect of anthropogenic sulfate and soot aerosol on the clear-sky planetary radiation budget, Geophys. Res. Lett., 22, 603-606, 1995.

Haywood, J. M. and Ramaswamy, V.: Global sensitivity studies of the direct radiative forcing due to anthropogenic sulfate and black carbon aerosols, J. Geophys. Res., 103, 6043-6058, 1998.

Hegg, D. A., Warren, S. G., Grenfell, T. C., Doherty, S. J., Larson, T. V., and Clarke, A. D.: Source Attribution of Black Carbon in Arctic Snow, Environ. Sci. Technol., 43, 4016-4021, doi:10.1021/es803623f, 2009.

Hegg, Dean A., Warren, Stephen G., Grenfell, Thomas C., Sarah J Doherty, and Clarke, Antony D.: Sources of light-absorbing aerosol in arctic snow and their seasonal variation, Atmos. Chem. Phys., 10, 10923-10938, doi:10.5194/acp-10-10923-2010, 2010.

Hirdman, D., Sodemann, H., Eckhardt, S., Burkhart, J. F., Jefferson, A., Mefford, T., Quinn, P. K., Sharma, S., Ström, J., and Stohl, A.: Source identification of short-lived air pollutants in the Arctic using statistical analysis of measurement data and particle dispersion model output, Atmos. Chem. Phys., 10, 669-693, doi:10.5194/acp-10-669-2010, 2010.

Hitzenberger, R., Petzold, A., Bauer, H., Ctyroky, P., Pouresmaeil, P., Laskus, L., and Puxbaum, H.: Intercomparison of Thermal and Optical Measurement Methods for Elemental Carbon and Black Carbon at an Urban Location, Environ. Sci. Technol., 40, 6377-6383, doi:10.1021/es051228v, 2006.

Holtslag, A. A. M., Debruijn, E. I. F., and Pan, H. L.: A high-resolution air-mass transformation model for short-range weather forecasting, Mon. Weather Rev., 118, 1561-1575, 1990.

Horvath, H.: Atmospheric light-absorption - a review, Atmos. Environ. A-gen., 27, 293-317, 1993.

Husain, L., Khan, A. J., Ahmed, T., Swami, K., Bari, A., Webber, J. S., and Li, J. J.: Trends in atmospheric elemental carbon concentrations from 1835 to 2005, J. Geophys. Res., 113, D13102, doi:10.1029/2007jd009398, 2008. 
Iversen, T. and Joranger, E.: Arctic air-pollution and large-scale atmospheric flows, Atmos. Environ., 19, 2099-2108, 1985.

Jacob, D. J., Crawford, J. H., Maring, H., Clarke, A. D., Dibb, J. E., Emmons, L. K., Ferrare, R. A., Hostetler, C. A., Russell, P. B., Singh, H. B., Thompson, A. M., Shaw, G. E., McCauley, E., Pederson, J. R., and Fisher, J. A.: The Arctic Research of the Composition of the Troposphere from Aircraft and Satellites (ARCTAS) mission: design, execution, and first results, Atmos. Chem. Phys., 10, 5191-5212, doi:10.5194/acp-10-5191-2010, 2010.

Jacobson, M. Z.: Strong radiative heating due to the mixing state of black carbon in atmospheric aerosols, Nature, 409, 695-697, 2001.

Jacobson, M. Z.: Climate response of fossil fuel and biofuel soot, accounting for soot's feedback to snow and sea ice albedo and emissivity, J. Geophys. Res., 109, D21201, doi:10.1029/2004jd004945, 2004.

Jacobson, M. Z.: Short-term effects of controlling fossil-fuel soot, biofuel soot and gases, and methane on climate, Arctic ice, and air pollution health, J. Geophys. Res., 115, D14209, doi:10.1029/2009jd013795, 2010.

Knutti, R. and Hegerl, G. C.: The equilibrium sensitivity of the Earth's temperature to radiation changes, Nat. Geosci., 1, 735743, doi:10.1038/ngeo337, 2008.

Koch, D. and Hansen, J.: Distant origins of Arctic black carbon: A Goddard Institute for Space Studies ModelE experiment, J. Geophys. Res., 110, D04204, doi:10.1029/2004jd005296, 2005.

Koch, D., Menon, S., Del Genio, A., Ruedy, R., Alienov, I., and Schmidt, G. A.: Distinguishing Aerosol Impacts on Climate over the Past Century, J. Clim., 22, 2659-2677, doi:10.1175/2008jcli2573.1, 2009a.

Koch, D., Schulz, M., Kinne, S., McNaughton, C., Spackman, J. R., Balkanski, Y., Bauer, S., Berntsen, T., Bond, T. C., Boucher, O., Chin, M., Clarke, A., De Luca, N., Dentener, F., Diehl, T., Dubovik, O., Easter, R., Fahey, D. W., Feichter, J., Fillmore, D., Freitag, S., Ghan, S., Ginoux, P., Gong, S., Horowitz, L., Iversen, T., Kirkevåg, A., Klimont, Z., Kondo, Y., Krol, M., Liu, X., Miller, R., Montanaro, V., Moteki, N., Myhre, G., Penner, J. E., Perlwitz, J., Pitari, G., Reddy, S., Sahu, L., Sakamoto, H., Schuster, G., Schwarz, J. P., Seland, Ø., Stier, P., Takegawa, N., Takemura, T., Textor, C., van Aardenne, J. A., and Zhao, Y.: Evaluation of black carbon estimations in global aerosol models, Atmos. Chem. Phys., 9, 9001-9026, doi:10.5194/acp-9-9001-2009, 2009b.

Koch, D. and Del Genio, A. D.: Black carbon semi-direct effects on cloud cover: review and synthesis, Atmos. Chem. Phys., 10, 7685-7696, doi:10.5194/acp-10-7685-2010, 2010.

Kristjansson, J. E.: Studies of the aerosol indirect effect from sulfate and black carbon aerosols, J. Geophys. Res., 107, 4246, doi:10.1029/2001jd000887, 2002.

Lamarque, J.-F., Bond, T. C., Eyring, V., Granier, C., Heil, A., Klimont, Z., Lee, D., Liousse, C., Mieville, A., Owen, B., Schultz, M. G., Shindell, D., Smith, S. J., Stehfest, E., Van Aardenne, J., Cooper, O. R., Kainuma, M., Mahowald, N., McConnell, J. R., Naik, V., Riahi, K., and van Vuuren, D. P.: Historical (1850-2000) gridded anthropogenic and biomass burning emissions of reactive gases and aerosols: methodology and application, Atmos. Chem. Phys., 10, 7017-7039, doi:10.5194/acp10-7017-2010, 2010.

Law, K. S. and Stohl, A.: Arctic air pollution: Origins and impacts,
Science, 315, 1537-1540, doi:10.1126/science.1137695, 2007.

Liao, H. and Seinfeld, J. H.: Global impacts of gas-phase chemistry-aerosol interactions on direct radiative forcing by anthropogenic aerosols and ozone, J. Geophys. Res., 110, D18208, doi:10.1029/2005jd005907, 2005.

Liu, J., Fan S., Horowitz, L. W., and Levy II, H.: Evaluation of factors controlling long-range transport of black carbon to the Arctic, J. Geophys. Res., 116, D04307, doi:10.1029/2010JD015145, 2011.

Liu, X. H., Penner, J. E., and Wang, M. H.: Influence of anthropogenic sulfate and black carbon on upper tropospheric clouds in the NCAR CAM3 model coupled to the IMPACT global aerosol model, J. Geophys. Res., 114, D03204, doi:10.1029/2008jd010492, 2009.

Lund, M. T. and Berntsen, T.: The importance of parameterization of black carbon aging in the OsloCTM2: Impacts on atmospheric burden and deposition in the Arctic, in preparation, 2011.

Mallet, M., Roger, J. C., Despiau, S., Putaud, J. P., and Dubovik, O.: A study of the mixing state of black carbon in urban zone, $\mathrm{J}$ Geophys. Res., 109, D04202 doi:10.1029/2003jd003940, 2004.

McConnell, J. R. and Edwards, R.: Coal burning leaves toxic heavy metal legacy in the Arctic, P. Natl. Acad. Sci. USA., 105, 12140 12144, doi:10.1073/pnas.0803564105, 2008.

McConnell, J. R., Edwards, R., Kok, G. L., Flanner, M. G., Zender, C. S., Saltzman, E. S., Banta, J. R., Pasteris, D. R., Carter, M. M., and Kahl, J. D. W.: 20th-century industrial black carbon emissions altered arctic climate forcing, Science, 317, 1381-1384, doi:10.1126/science.1144856, 2007.

Myhre, G., Bellouin, N., Berglen, T. F., Berntsen, T. K., Boucher, O., Grini, A., Isaksen, I. S. A., Johnsrud, M., Mishchenko, M. I., Stordal, F., and Tanre, D.: Comparison of the radiative properties and direct radiative effect of aerosols from a global aerosol model and remote sensing data over ocean, Tellus B, 59, 115-129, 2007.

Myhre, G.: Consistency Between Satellite-Derived and Modeled Estimates of the Direct Aerosol Effect, Science, 325, 187-190, doi:10.1126/science.1174461, 2009.

Myhre, G., Berglen, T. F., Johnsrud, M., Hoyle, C. R., Berntsen, T. K., Christopher, S. A., Fahey, D. W., Isaksen, I. S. A., Jones, T. A., Kahn, R. A., Loeb, N., Quinn, P., Remer, L., Schwarz, J. P., and Yttri, K. E.: Modelled radiative forcing of the direct aerosol effect with multi-observation evaluation, Atmos. Chem. Phys., 9, 1365-1392, doi:10.5194/acp-9-1365-2009, 2009.

Ohara, T., Akimoto, H., Kurokawa, J., Horii, N., Yamaji, K., Yan, X., and Hayasaka, T.: An Asian emission inventory of anthropogenic emission sources for the period 19802020, Atmos. Chem. Phys., 7, 4419-4444, doi:10.5194/acp-7-4419-2007, 2007.

Penner, J. E., Chen, Y., Wang, M., and Liu, X.: Possible influence of anthropogenic aerosols on cirrus clouds and anthropogenic forcing, Atmos. Chem. Phys., 9, 879-896, doi:10.5194/acp-9-8792009, 2009.

Prather, M. J.: Numerical advection by conservation of 2nd-order moments, J. Geophys. Res., 91, 6671-6681, 1986.

Quinn, P. K., Bates, T. S., Baum, E., Doubleday, N., Fiore, A. M., Flanner, M., Fridlind, A., Garrett, T. J., Koch, D., Menon, S., Shindell, D., Stohl, A., and Warren, S. G.: Short-lived pollutants in the Arctic: their climate impact and possible mitigation strategies, Atmos. Chem. Phys., 8, 1723-1735, doi:10.5194/acp8-1723-2008, 2008. 
Ramanathan, V. and Carmichael, G.: Global and regional climate changes due to black carbon, Nat. Geosci., 1, 221-227, 2008.

Rypdal, K., Rive, N., Berntsen, T. K., Klimont, Z., Mideksa, T. K., Myhre, G., and Skeie, R. B.: Costs and global impacts of black carbon abatement strategies, Tellus B, 61, 625-641, doi:10.1111/j.1600-0889.2009.00430.x, 2009.

Schulz, M., Textor, C., Kinne, S., Balkanski, Y., Bauer, S., Berntsen, T., Berglen, T., Boucher, O., Dentener, F., Guibert, S., Isaksen, I. S. A., Iversen, T., Koch, D., Kirkevåg, A., Liu, X., Montanaro, V., Myhre, G., Penner, J. E., Pitari, G., Reddy, S., Seland, Ø., Stier, P., and Takemura, T.: Radiative forcing by aerosols as derived from the AeroCom present-day and pre-industrial simulations, Atmos. Chem. Phys., 6, 5225-5246, doi:10.5194/acp-6-5225-2006, 2006.

Schwarz, J. P., Spackman, J. R., Gao, R. S., Watts, L. A., Stier, P., Schulz, M., Davis, S. M., Wofsy, S. C., and Fahey, D. W.: Global-scale black carbon profiles observed in the remote atmosphere and compared to models, Geophys. Res. Lett., 37, L18812, doi:10.1029/2010g1044372, 2010.

Sharma, S., Lavoue, D., Cachier, H., Barrie, L. A., and Gong, S. L.: Long-term trends of the black carbon concentrations in the Canadian Arctic, J. Geophys. Res., 109, D15203, doi:10.1029/2003JD004331, 2004.

Sharma, S., Andrews, E., Barrie, L. A., Ogren, J. A., and Lavoue, D.: Variations and sources of the equivalent black carbon in the high Arctic revealed by long-term observations at Alert and Barrow: 1989-2003, J. Geophys. Res., 111, D14208, doi:10.1029/2005JD006581, 2006.

Shaw, G. E.: The arctic haze phenomenon, B. Am. Meteorol. Soc., 76, 2403-2413, 1995.

Shaw, G. E. and Stamnes, K.: Arctic haze: perturbation of the polar radiation budget, Ann. N. Y. Acad. Sci., 338, 533-539, doi:10.1111/j.1749-6632.1980.tb17145.x, 1980.

Shindell, D. and Faluvegi, G.: Climate response to regional radiative forcing during the twentieth century, Nat. Geosci., 2, 294 300, doi:10.1038/ngeo473, 2009.

Shindell, D. T., Chin, M., Dentener, F., Doherty, R. M., Faluvegi, G., Fiore, A. M., Hess, P., Koch, D. M., MacKenzie, I. A., Sanderson, M. G., Schultz, M. G., Schulz, M., Stevenson, D. S., Teich, H., Textor, C., Wild, O., Bergmann, D. J., Bey, I., Bian, H., Cuvelier, C., Duncan, B. N., Folberth, G., Horowitz, L. W., Jonson, J., Kaminski, J. W., Marmer, E., Park, R., Pringle, K. J., Schroeder, S., Szopa, S., Takemura, T., Zeng, G., Keating, T. J., and Zuber, A.: A multi-model assessment of pollution transport to the Arctic, Atmos. Chem. Phys., 8, 5353-5372, doi:10.5194/acp-8-5353-2008, 2008.

Smith, S. J., van Aardenne, J., Klimont, Z., Andres, R. J., Volke, A., and Delgado Arias, S.: Anthropogenic sulfur dioxide emissions: 1850-2005, Atmos. Chem. Phys., 11, 1101-1116, doi:10.5194/acp-11-1101-2011, 2011.

Stamnes, K., Tsay, S. C., Wiscombe, W., and Jayaweera, K.: Numerically stable algorithm for discrete-ordinate-method radiative-transfer in multiple-scattering and emitting layered media, Appl. Opt., 27, 2502-2509, 1988.

Stier, P., Feichter, J., Kloster, S., Vignati, E., and Wilson, J.: Emission-Induced Nonlinearities in the Global Aerosol System: Results from the ECHAM5-HAM Aerosol-Climate Model, J. Clim., 19, 3845-3862, doi:10.1175/JCLI3772.1, 2006.

Stohl, A.: Characteristics of atmospheric transport into the Arctic troposphere, J. Geophys. Res., 111, D11306, doi:10.1029/2005jd006888, 2006.

Stohl, A., Berg, T., Burkhart, J. F., Fjæraa, A. M., Forster, C., Herber, A., Hov, Ø., Lunder, C., McMillan, W. W., Oltmans, S., Shiobara, M., Simpson, D., Solberg, S., Stebel, K., Ström, J., Tørseth, K., Treffeisen, R., Virkkunen, K., and Yttri, K. E. Arctic smoke - record high air pollution levels in the European Arctic due to agricultural fires in Eastern Europe in spring 2006, Atmos. Chem. Phys., 7, 511-534, doi:10.5194/acp-7-511-2007, 2007.

Søvde, O. A., Gauss, M., Smyshlyaev, S. P., and Isaksen, I. S. A.: Evaluation of the chemical transport model Oslo CTM2 with focus on arctic winter ozone depletion, J. Geophys. Res., 113, D09304, doi:10.1029/2007jd009240, 2008.

Tiedtke, M.: A comprehensive mass flux scheme for cumulus parameterization in large-scale models, Mon. Weather Rev., 117, 1779-1800, 1989.

Trenberth, K., Jones, P., Ambenje, P., Bojariu, R., Easterling, D., Tank, A., Parker, D., Rahimzadeh, F., Renwick, J., Rusticucci, M., Soden, B., and Zhai, P.: Observations: Surface and Atmospheric Climate Change, in: Climate Change 2007: The Physical Science Basis. Contribution of Working Group I to the Fourth Assessment Report of the Intergovernmental Panel on Climate, edited by: Solomon, S., Qin, D., Manning, M., Chen, Z., Marquis, M., Averyt, K. B., Tignor, M., and Miller, H. L., Cambridge Univ. Press, New York, 2007.

Tsyro, S., Simpson, D., Tarrason, L., Klimont, Z., Kupiainen, K., Pio, C., and Yttri, K. E.: Modeling of elemental carbon over Europe, J. Geophys. Res., 112, D23S19, doi:10.1029/2006jd008164, 2007.

van der Werf, G. R., Randerson, J. T., Giglio, L., Collatz, G. J., Kasibhatla, P. S., and Arellano Jr., A. F.: Interannual variability in global biomass burning emissions from 1997 to 2004, Atmos. Chem. Phys., 6, 3423-3441, doi:10.5194/acp-6-3423-2006, 2006.

Vignati, E., Wilson, J., and Stier, P.: M7: An efficient size-resolved aerosol microphysics module for large-scale aerosol transport models, J. Geophys. Res., 109, D22202 doi:10.1029/2003jd004485, 2004.

Vignati, E., Karl, M., Krol, M., Wilson, J., Stier, P., and Cavalli, F.: Sources of uncertainties in modelling black carbon at the global scale, Atmos. Chem. Phys., 10, 2595-2611, doi:10.5194/acp-102595-2010, 2010.

Warneke, C., Bahreini, R., Brioude, J., Brock, C. A., de Gouw, J. A., Fahey, D. W., Froyd, K. D., Holloway, J. S., Middlebrook, A., Miller, L., Montzka, S., Murphy, D. M., Peischl, J., Ryerson, T. B., Schwarz, J. P., Spackman, J. R., and Veres, P.: Biomass burning in Siberia and Kazakhstan as an important source for haze over the Alaskan Arctic in April 2008, Geophys. Res. Lett., 36, L02813, doi:10.1029/2008g1036194, 2009.

Warneke, C., Froyd, K. D., Brioude, J., Bahreini, R., Brock, C. A., Cozic, J., de Gouw, J. A., Fahey, D. W., Ferrare, R., Holloway, J. S., Middlebrook, A. M., Miller, L., Montzka, S., Schwarz, J. P., Sodemann, H., Spackman, J. R., and Stohl, A.: An important contribution to springtime Arctic aerosol from biomass burning in Russia, Geophys. Res. Lett., 37, L01801, doi:10.1029/2009g1041816, 2010.

Warren, S. G. and Wiscombe, W. J.: A model for the spectral albedo of snow 2. Snow containing atmospheric aerosols, J. Atmos. Sci., 
37, 2734-2745, 1980.

Warren, S. G. and Clarke, A. D.: Soot in the atmosphere and snow surface of Antarctica, J. Geophys. Res., 95, 1811-1816, 1990.

Wentzel, M., Gorzawski, H., Naumann, K. H., Saathoff, H., and Weinbruch, S.: Transmission electron microscopical and aerosol dynamical characterization of soot aerosols, J. Aerosol Sci., 34, 1347-1370, doi:10.1016/s0021-8502(03)00360-4, 2003.

Yttri, K. E., Simpson, D., Nøjgaard, J. K., Kristensen, K., Genberg, J., Stenström, K., Swietlicki, E., Hillamo, R., Aurela, M., Bauer, H., Offenberg, J. H., Jaoui, M., Dye, C., Eckhardt, S., Burkhart, J. F., Stohl, A., and Glasius, M.: Source apportionment of the summer time carbonaceous aerosol at Nordic rural background sites, Atmos. Chem. Phys. Discuss., 11, 16369-16416, doi:10.5194/acpd-11-16369-2011, 2011.
Zarzycki, C. M. and Bond, T. C.: How much can the vertical distribution of black carbon affect its global direct radiative forcing?, Geophys. Res. Lett., 37, L20807, doi:10.1029/2010g1044555, 2010.

Zhang, X. Y., Wang, Y. Q., Zhang, X. C., Guo, W., and Gong, S. L.: Carbonaceous aerosol composition over various regions of China during 2006, J. Geophys. Res., 113, D14111 doi:10.1029/2007jd009525, 2008. 